\title{
THE POLITICAL ECONOMY OF SCIENTIFIC MEDICINE: SCIENCE, EDUCATION AND THE TRANSFORMATION OF MEDICAL PRACTICE IN SHEFFIELD, 1890-1922
}

\author{
by
}

STEVE STURDY*

\section{INTRODUCTION}

One of the most striking developments in twentieth-century medicine has been the growing involvement of laboratory science in day-to-day medical practice. Not only are scientific laboratories employed extensively in the diagnosis and investigation of illness, but it is now commonplace to regard doctors as, in many ways, applied scientists. This is a far cry from the situation at the end of the nineteenth century, when few hospitals had more than rudimentary laboratory facilities, and few clinicians made more than cursory use of them. At that time, laboratories were just starting to play a part in the practice of medicine. Microscopic techniques had begun to be incorporated into post-mortem examinations from the mid-nineteenth century. And with the proliferation of new bacteriological techniques from the $1880 \mathrm{~s}$, diagnostic laboratories came to be used routinely, first in public health work, and subsequently in hospitals. ${ }^{1}$ Gradually, a minority of clinicians also began to undertake their own research in hospital laboratories, and by the 1920s a few university teaching hospitals were providing full-time scientists with clinical facilities for the purposes of research, teaching and healing. ${ }^{2}$ From these beginnings, medical practice came increasingly to revolve around the work of laboratories, both as technical resources for the routine

* Steven W. Sturdy, MA, Ph.D., Wellcome Unit for the History of Medicine, Mathematics Tower, The University, Manchester M13 9PL.

Earlier versions of this paper were given to the Society for the Social History of Medicine, Sheffield University, 8 October 1990, and to the Section of the History of Medicine, Yale University, 23 April 1991. I would particularly like to thank David Cantor, Roger Cooter, Mary Fissell, Bill Luckin, John Pickstone, Michael Worboys, and three anonymous referees for Medical History for their detailed and constructive criticisms of earlier drafts. I would also like to thank Peter A. Linacre, Honorary Archivist at the University of Sheffield, for guiding me to the archives on which this work is based.

${ }^{1}$ Dorothy Watkins, 'The English revolution in social medicine, 1889-1911', Ph.D. thesis, University of London, 1984; Barbara Gutmann Rosenkrantz, Public health and the state: changing views in Massachusetts, 1842-1936, Cambridge, Mass., Harvard University Press, 1972; W. D. Foster, A short history of clinical pathology, Edinburgh, Livingstone, 1961; Edward T. Morman, 'Clinical pathology in America, 1865-1915: Philadelphia as a test case', Bull. Hist. Med., 1984, 58: 198-214.

2 A. McGehee Harvey, Science at the bedside: clinical research in American medicine, 1905-1945, Baltimore, Johns Hopkins University Press, 1981; Christopher C. Booth, 'Clinical research', in Joan Austoker and Linda Bryder (eds), Historical perspectives on the role of the MRC: essays in the history of the Medical 
investigation of patients, and as producers of the kind of knowledge and techniques that we now see as characteristic of scientific medicine. ${ }^{3}$

Historians of science and medicine have investigated these early transformations in some detail. But over the past twenty years or so, it has become increasingly unclear just what kind of explanation ought to be sought for the growth of medical laboratories at this time, and especially for their gradual involvement in medical practice. The assumption that science was valued because it led directly to improvements in therapeutic and diagnostic technique has been challenged by some of the best recent work in the history of medicine. At the time, many leading medical practitioners simply did not see laboratory science as particularly beneficial. On the contrary, a substantial body of medical opinion held that reliance on the laboratory or on the knowledge that it produced was actually prejudicial to good practice. ${ }^{4}$ And while it is tempting to explain away this medical reaction as a product of narrow self-interest or sheer bloodymindedness, a less partisan approach has proved more illuminating: by remaining agnostic about the supposed benefits of scientific innovations, a number of historians have shown how professional and other social interests informed, not just clinicians' doubts about the value of science, but also scientists' claims for the clinical relevance of their own work. ${ }^{5}$ In other words, judgments of the benefits that science brought to medical practice are themselves subjects for historical explanation, and thus are no longer seen to offer an adequate explanation of the development of scientific medicine. ${ }^{6}$

Rather, it has become necessary to seek more sophisticated and nuanced accounts of the historical factors that lay behind the advocacy of science in medicine, and especially behind clinicians' eventual adoption of the view that science did, indeed, have something to offer. On the whole, however, recent work has tended to emphasize the divergence between scientists' and clinicians' interests in science and medical practice. Thus, on the one hand, historians have shown how scientists sought to annex clinical medicine as a field in which they could pursue existing lines of academic research and

Research Council of the United Kingdom and its predecessor, the Medical Research Committee, 1913-53, Oxford University Press, 1989, pp. 205-41.

${ }^{3}$ Ronald L. Numbers and John Harley Warner have recently emphasized that other periods and other cultures may have their own science of medicine, and that to speak of scientific medicine in the singular is thus to assume an ethnocentric point of view: see their paper on 'The maturation of American medical science', in Nathan Reingold and Marc Rothenberg (eds), Scientific colonialism, 1800-1930: a crosscultural comparison, Washington, D.C., Smithsonian Institution Press, 1987. This caveat is well taken. However, as a matter of convenience, I propose to use the term "scientific medicine" in this paper to designate the recognizably modern alliance of the laboratory with medical practice.

${ }^{4}$ See Christopher Lawrence, 'Incommunicable knowledge: science, technology and the clinical art in Britain 1850-1914', J. contemp. Hist., 1985, 20: 503-20.

${ }^{5}$ Gerald L. Geison, 'Divided we stand: physiologists and clinicians in the American context', and Russell C. Maulitz, "Physician versus bacteriologist": the ideology of science in clinical medicine', both in Morris J. Vogel and Charles E. Rosenberg (eds), The therapeutic revolution: essays in the social history of American medicine, Philadelphia, University of Pennsylvania Press, 1979, pp. 67-90 and 91-107 respectively. Even where clinicians and scientists collaborated closely in developing medical innovations, divergent professional interests could lead to divergent views on questions of efficacy and ethics: see Gerald $L$. Geison, 'Pasteur, Roux, and rabies: scientific versus clinical mentalities', J. Hist. Med., 1990, 45: 341-65. And for a series of detailed case studies of the social basis of scientific innovation in medicine, see $J$. V. Pickstone (ed.), Medical innovation in historical perspective, London, Macmillan, 1992.

${ }^{6}$ A valuable review of American scholarship in this field prior to 1985 is John Harley Warner, 'Science in medicine', Osiris, 2nd series, 1985, 1: 37-58. 
teaching, with little regard for the practical concerns of doctors. ${ }^{7}$ And on the other hand, clinicians have been portrayed as adopting new scientific knowledge and laboratory-based techniques for primarily ornamental purposes: while a display of science may have helped to enhance clinicians' prestige in the eyes of patrons and patients, the influence that new technologies were allowed to have on the actual process of clinical decision-making was strictly limited. ${ }^{8}$ Such studies not only imply that scientists and clinicians had few interests in common, but also that neither group was particularly interested in reforming medical practice. ${ }^{9}$ Consequently, historians have tended to try and explain clinicians' cautious acceptance of laboratory science in terms of cultural as opposed to practical benefits: scientific training, in particular, is seen as having provided a new source of cultural authority which was instrumental in raising the social status of the medical profession at the time. ${ }^{10}$ But this begs the question: why should doctors and patients have regarded laboratory science as a source of cultural authority in the first place? Indeed, far from being able to turn to science as an established source of authority, nineteenth-century medical practitioners were themselves among the most influential proponents and architects of a new culture in which science was so regarded. ${ }^{11}$

\footnotetext{
${ }^{7}$ See, for example, Joan Austoker, 'Walter Morley Fletcher and the origins of a basic biomedical research policy', and David Cantor, 'The MRC's support for experimental radiology during the inter-war years', both in Austoker and Bryder (eds), op. cit., note 2 above, pp. 23-33 and 181-204 respectively. Charles Rosenberg has emphasized the importance of social and institutional context in shaping scientists' disciplinary interests: Rosenberg, 'Toward an ecology of knowledge: on discipline, context, and history', in Alexandra Oleson and John Voss (eds), The organization of knowledge in modern America, Baltimore, Johns Hopkins University Press, 1979, pp. 440-55. Nevertheless, such an approach persists in placing scientists centre stage, and hence in contrasting their interests with those of the clinicians and others to whom they looked for support. See, for instance, Robert E. Kohler, From medical chemistry to biochemistry: the making of a biomedical discipline, Cambridge University Press, 1982, pp. 40-92.

${ }^{8}$ S. E. D. Shortt has argued that laboratory science was introduced into medical education in the second half of the nineteenth century because it was now seen as an important part of a liberal education, and that it was accepted by doctors precisely because it failed to have any immediate implications for practice: Shortt, 'Physicians, science and status: issues in the professionalization of Anglo-American medicine in the nineteenth century', Med. Hist., 1983, 27: 51-68. Detailed studies of the involvement of new diagnostic techniques in clinical practice tend to bear this out: see L. S. Jacyna, 'The laboratory and the clinic: the impact of pathology on surgical diagnosis in the Glasgow Western Infirmary, 1875-1910', Bull. Hist. Med., 1988, 62: 384 406; Joel D. Howell, 'Early use of X-ray machines and electrocardiographs at the Pennsylvania Hospital', J.A.M.A., 1986, 255: 2320-3.

${ }^{9}$ In stressing the tendency of historians to polarize the interests of scientists and clinicians, it should not be supposed that collaboration between the two groups, and the gradual integration of their respective bodies of knowledge and practice, has been ignored. See, for instance: Christopher Lawrence, 'Moderns and ancients: the "new cardiology" in Britain 1880-1930', Med. Hist., Supplement No. 5, 1985, 1-33; Joel D. Howell, 'Cardiac physiology and clinical medicine? Two case studies', in Gerald L. Geison (ed.), Physiology in the American context 1850-1940, Bethesda, American Physiological Society, 1987, pp. 279-92; Susan Leigh Star, Regions of the mind: brain research and the quest for scientific certainty, Stanford University Press, 1989. What such accounts lack, however, is a satisfactory historical account of the interests that led to and sustained this integration.

${ }^{10}$ Rosemary Stevens, The practice of medicine in modern England, New Haven, Yale University Press, 1966; idem, American medicine and the public interest, New Haven, Yale University Press, 1971; Paul Starr, The social transformation of American medicine, New York, Basic Books, 1982; Barbara G. Rosenkrantz, 'The search for professional order in 19th century American medicine', Proceedings of the 14th International Congress on the History of Science, Tokyo, Science Council of Japan, 1975, no. 4, pp. 113-24.

11 John Harley Warner, 'Ideals of science and their discontents in late-nineteenth-century American medicine', Isis, 1991, 82: 454-78. And on Britain, see Ian Inkster, 'Marginal men: aspects of the social role
} 


\section{Steve Sturdy}

What is needed, then, is an account of just what doctors might have expected to gain by allying themselves to the development of science, be it in terms of practical or of social advantages over their competitors and their patients. This paper is an attempt to develop such an account. It starts from the recognition that, in some cases at least, late nineteenth- and early twentieth-century scientists and clinicians did in fact collaborate in promoting forms of medical science which were intended to engage directly with medical practice. Moreover, it argues that the involvement of science in medicine led to changes in medical practice which help to account for the growth of professional and, to an extent, lay support for science at that time. But while conventional accounts have supposed that the practical effects of science must be sought in terms of improvements in diagnostic and therapeutic efficacy, this paper looks elsewhere. It argues that the most important changes in medical practice were to be found in the sphere of what might best be termed medical administration.

A number of historians have observed that the work of doctors became increasingly administrative or managerial from the turn of the twentieth century onwards. This is particularly clear where medicine was involved in the service of large-scale organizations like industry and the military. ${ }^{12}$ But the same analysis can also be extended to other aspects of twentieth-century medical practice: increasingly, medicine has become a corporate enterprise involving a considerable load of administrative work, for instance in rationing access to health care facilities. ${ }^{13}$ And within this corporate world, there are indications that science has been closely allied to the pursuit of administrative efficiency. This has been well documented in the case of hospitals, themselves increasingly corporate institutions by the start of the twentieth century, where the emergence of scientific medicine coincided with a growing interest in "scientific management". ${ }^{14}$ The same concern with medical efficiency has also been discerned in the massive financial support for scientific medicine provided by such corporate bodies as the Rockefeller Foundation, and in the growth of social insurance and the reorganization of medical care more generally. ${ }^{15}$

\footnotetext{
of the medical community in Sheffield 1790-1850', in John Woodward and David Richards (eds), Health care and popular medicine in nineteenth century England, London, Croom Helm, 1977, pp. 128-63; Arnold Thackray, 'Natural knowledge in cultural context: the Manchester model', Am. hist. Rev., 1974, 79: 672-709; Robert H. Kargon, Science in Victorian Manchester: enterprise and expertise, Manchester University Press, 1977.

12 Paul Weindling (ed.), The social history of occupational health, London, Croom Helm, 1985; Angela Nugent, 'Fit for work: the introduction of physical examinations in industry', Bull. Hist. Med., 1983, 57: 578-95; Roger Cooter, 'Medicine and the goodness of war', Canadian Bull. of med. Hist., 1990, 7: 147-59.

${ }^{13}$ Deborah Stone, 'Physicians as gatekeepers: illness certification as a rationing device,' Public Policy, 1979, 27: 227-54.

${ }^{14}$ Susan Reverby, 'Stealing the golden eggs: Ernest Amory Codman and the science and management of medicine', Bull. Hist. Med., 1981, 55: 156-71; Morris Vogel, 'Managing medicine: creating a profession of hospital administration in the United States, 1895-1915', in Lindsay Granshaw and Roy Porter (eds), The hospital in history, London, Routledge, 1989, pp. 234-60; Charles Rosenberg, 'Inward vision and outward glance: the shaping of the American hospital, 1880-1914', Bull. Hist. Med., 1979, 53: 346-91.

${ }^{15}$ E. Richard Brown, Rockefeller medicinemen: medicine and capitalism in America, Berkeley, University of California Press, 1979; Howard S. Berliner, A system of scientific medicine: philanthropic foundations in the
} 
Other authors have indicated ways in which the laboratory sciences might have contributed to the pursuit of administrative efficiency in medicine. Thus, for Bruno Latour, the bacteriology laboratory proved useful to public health administrators because it enabled them to specify far more localized sites for sanitary intervention. ${ }^{16}$ In similar vein, a number of researchers have suggested that the redefinition of certain kinds of illness according to new scientific theories, and the introduction of new diagnostic technologies, may have made it possible to decide more rapidly which patients would respond to treatment, and which would merely become a drain on resources. ${ }^{17}$ In both these cases, it seems that the development of scientific knowledge and scientific technique made it possible to divide up or conceptualize populations and their environment in ways which permitted more economical forms of medical management, without necessarily implying any change in therapeutic technique.

Moreover, a considerable body of research on the development of the medical profession has pointed to the relationship between the growth of medical science and the emergence of a new division of medical labour. While much of this work continues to suppose that specialization is driven, at least in part, by the development of new therapeutic and diagnostic techniques, it might equally be suggested that the scientific reorganization of medical knowledge was in fact a response to the perceived need for a reorganization of medical work: in effect, the pursuit of medical science might thus be seen as a way of restructuring the machinery of medical management itself, once again in the interests of administrative efficiency. ${ }^{18}$

This paper pursues these arguments through a case study of the development of scientific medicine in Sheffield - an industrial city in the north of England-in the late nineteenth and early twentieth centuries. It aims to show how due attention to the administrative aspects of modern medicine can help us to understand the growth of medical science at this time. And in particular, it shows how the scientific reorganization of medical knowledge helped to establish a new hierarchy of medical

Flexner era, New York, Tavistock Publications, 1985; Stephen J. Kunitz, 'Efficiency and reform in the financing and organization of American medicine in the Progressive Era', Bull. Hist. Med., 1981, 55: 497-515.

${ }^{16}$ Bruno Latour, The Pasteurization of France, transl. Alan Sheridan and John Law, London, Harvard University Press, 1988.

${ }^{17}$ Thus Joel D. Howell has shown how the physiological redefinition of heart disease during the First World War increased the rate at which disabled soldiers were either discharged or returned to combat: Howell, "'Soldiers's heart": the redefinition of heart disease and speciality formation in early twentiethcentury Great Britain', Med. Hist., Supplement No. 5, 1985: 34-52. Martin S. Pernick has discussed an earlier instance of the use of science to decide who should and who should not receive anaesthetics, in his $A$ calculus of suffering: pain, anaesthesia and utilitarian professionalism in nineteenth-century American medicine, New York, Columbia University Press, 1985. On the persistence of this concern with classification and prognosis in more recent medical science, see Stephen J. Kunitz, 'Classifications in medicine', in Russell C. Maulitz and Diana E. Long (eds), Grand rounds: one hundred years of internal medicine, Philadelphia, University of Pennsylvania Press, 1988, pp. 279-96.

${ }^{18}$ Daniel M. Fox, Health policies, health politics: the British and American experience 1911-1965, Princeton University Press, 1986. Harry M. Marks makes a related case for viewing randomized control trials as a technique for managing the behaviour of medical practitioners in the interests of producing standardized therapeutic knowledge: Marks, 'Notes from the underground: the social organization of therapeutic trials', in Maulitz and Long, op. cit., note 17 above, pp. 297-336. See also Rosemary Stevens's thoughtful essay on 'The curious career of internal medicine: functional ambivalence, social success', in ibid., op. cit., note 17 above, pp. 339-64. 


\section{Steve Sturdy}

practice that was seen to be more appropriate to the administrative needs of health care in the city. ${ }^{19}$

\section{MEDICAL SCIENCE IN A CIVIC UNIVERSITY}

To begin, let us look at how medical science laboratories first came to be established in Sheffield. To an extent, this reflected reforms in medical education that took effect across Britain in the late nineteenth century. A medical school had been established in Sheffield in 1828 , to provide local medical apprentices with the training in anatomy and other subjects that they needed to fulfil the licensing requirements of the Society of Apothecaries and the Royal College of Surgeons of England. ${ }^{20}$ Initially, the School had flourished. But from the mid-nineteenth century, the metropolitan licensing bodies and some of the élite universities began to set new standards for pre-clinical education by emphasizing practical laboratory training, particularly in physiology and pathology. At first, the Sheffield Medical School continued to adhere to an older model of pre-clinical education, which restricted practical experience to anatomical dissection, while physiology and pathology were taught entirely in the lecture theatre. But, as the more ambitious students moved elsewhere for their pre-clinical training, the staff became demoralized, and by the early 1880 s some were even calling for the School to be closed. ${ }^{21}$ In the end, the staff decided to adopt a strategy of expansion and reform which would eventually bring the Sheffield School more closely into line with pre-clinical science teaching elsewhere in Britain. From 1882, the school began collaborating with the other higher education institutions in the city to provide new scientific facilities: over the next twenty years, full-time professors of anatomy, physiology and pathology were appointed, physiology and pathology laboratories were set up, and by 1905 this had led to the creation of an independent University in the city, of which the Medical School became a Faculty. ${ }^{22}$

${ }^{19}$ Roger Cooter develops a closely related set of arguments, but from the perspective of a single medical specialism, in his Surgery and society in peace and war: orthopaedics and the organisation of modern medicine, 1880-1948, London, Macmillan, in press. John V. Pickstone's discussion of medical science and the specialization of hospital work in another northern industrial city has also provided useful insights: Pickstone, 'Sciences, specialists and capital: the modernisation of Manchester hospitals', chapter 9 of his Medicine and industrial society: a history of hospital development in Manchester and its region, 1752-1946, Manchester University Press, 1985. The classic work on the establishment of a hierarchical structure of management in corporate industrial enterprises at this time is Alfred $\mathrm{R}$. Chandler, The visible hand: the managerial revolution in American business, Cambridge, Mass., Harvard University Press, 1977.

20 For the early years of the Medical School, cf. William Smith Porter, The Medical School in Sheffield, 1828-1928, Sheffield, J. W. Northend, 1928. See also John G. McCrie, 'The Sheffield Medical School', Hist. Med., 1973, 5, No. 2, 3-6. Cf. S. T. Anning, 'Provincial medical schools in the nineteenth century', in F. N. L. Poynter (ed.), The evolution of medical education in Britain, London, Putnam Medical, 1966, pp. 121-34.

${ }^{21}$ For descriptions of the run-down premises, the unenthusiastic teaching, and the poor quality of the students around 1880, see: Arthur Hall, The Sheffield School of Medicine (Some personal notes on the history of the Sheffield School of Medicine during the last half-century or more), bound typescript deposited in Sheffield University Library, 1944; A. E. Barnes, 'Medical student days', typescript, Sheffield University Archives (hereafter SUA) 5/1/26, ff. 3-27. Hall and Barnes later became deeply involved in reforming the curriculum, and their recollections are perhaps exaggerated. Nevertheless, the pressure to close the School was real enough: see Porter, op. cit., note 20 above, p. 71.

${ }^{22}$ See Arthur W. Chapman, The story of a modern university: a history of the University of Sheffield, Oxford University Press, 1955. The other relevant institutions were Firth College, which trained students for 


\section{The political economy of scientific medicine}

If a national reform movement helped to stimulate the development of medical laboratories in Sheffield, however, local circumstances also played an important role in creating the programme of medical science that took shape there. The new University was one of the poorest in the country, and had to struggle to compete with its neighbours. ${ }^{23}$ Compared with mercantile centres like Liverpool and Manchester, the city's industrial wealth was divided between a relatively large number of small manufacturers: few individual fortunes were made, and few large endowments were available to fund laboratories and chairs. ${ }^{24}$ As a result, the University depended to an unusual extent on the continuing support, both financial and political, that it was able to generate by providing technical and educational services for local industry. ${ }^{25}$ The Medical School struggled under the same financial constraints, ${ }^{26}$ and likewise relied heavily both on service work and local authority interest. Public health administration, in particular, proved to be a valuable source of income. Thus in 1897 the Medical Officer of Health (MOH) to the city was made honorary professor of public health in the Medical School, an appointment extended to successive MOsH up to 1949. At the time, the Sheffield health authority was playing a prominent role in the development of notification schemes for the control of infectious diseases, notably tuberculosis. ${ }^{27}$ Bacteriological identification of infectious individuals was central to

external degrees from the University of London and other qualifications, and the Technical School. In 1897 the three schools amalgamated to form University College, Sheffield, which was awarded a full university charter in 1905. Cf. Stella V. F. Butler, 'A transformation in training: the formation of university medical faculties in Manchester, Leeds, and Liverpool, 1870-84', Med. Hist., 1986, 30: 115-32.

${ }^{23}$ Before gaining its own university charter, University College, Sheffield, had sought membership of the Victoria University, which incorporated the university colleges of Manchester, Liverpool and Leeds, but had been rejected on the grounds that its science teaching facilities were inadequate: Chapman, op. cit., note 22 above, pp. 92-8, 133-48, 176-8.

${ }^{24}$ On the class structure and politics of Sheffield, see: Sidney Pollard, A history of labour in Sheffield, Liverpool University Press, 1959; and Dennis Smith, Conflict and compromise: class formation in English society 1830-1914. A comparative study of Birmingham and Sheffield, London, Routledge \& Kegan Paul, 1982. On endowments, see Michael Sanderson, The universities and British industry 1850-1970, London, Routledge \& Kegan Paul, 1972, pp. 68, 78-81.

${ }^{25}$ Michael Sanderson, 'The professor as industrial consultant: Oliver Arnold and the British steel industry, 1900-14', Econ. Hist. Rev., 1978, 31: 585-600, describes the relationship between industrial consultancy and the growth of the University's metallurgy department. Similar industrial interests were reflected in other forms of political and financial support for university education in the city. Thus Sheffield politicians and educationalists played a prominent part in the national campaign for Treasury grants for universitylevel education in the late 1880s: Chapman, op. cit., note 22 above, pp. 44-67. But the greatest single source of income was the annual grant awarded by the City Council, the largest paid to any provincial university. In 1913-14 this stood at $£ 17,226$, compared to the next largest grant of $£ 16,022$ to Leeds University; by 1921-22 these figures had grown to $£ 39,691$ as compared to $£ 28,766$ for Leeds. 'Memorandum from the sister Universities of Birmingham, Durham, Leeds, Liverpool, Manchester and Sheffield to the Prime Minister', 10 December 1921, in UGC papers, 1919-34, Public Record Office (PRO) Ed 24/1977.

${ }^{26}$ The new laboratories and full-time teaching posts were partly endowed with funds from old Medical School teachers: Chapman, op. cit., note 22 above, pp. 124, 126-7. Nevertheless, finances remained tight following the creation of an independent university. Thus in 1905, the Medical Faculty proposed across-the-board increases in the salaries of the pre-clinical science professors; even so, salaries remained considerably lower than in other provincial universities: Medical Faculty, 'Academic salary comparisons with other Universities', 1905, SUA 5/1/76.

${ }_{27}$ The central figure in these developments was John Robertson, MOH for Sheffield and professor of public health from 1897 to 1903 , and subsequently $\mathrm{MOH}$ for Birmingham. Robertson was a prominent national figure in the development of tuberculosis services. In 1899, under his guidance, Sheffield became one of the first local authorities to establish a voluntary tuberculosis notification scheme, which in 1903 became the first compulsory scheme in Britain. On Robertson, see obituaries: Lancet, 1936, ii: 1548-9; Brit. 
these schemes, which generated a considerable volume of routine laboratory tests. By undertaking this work on a fees-for-service basis, the School was able to finance teaching laboratories, a full-time professor and other teaching and research staff in pathology. ${ }^{28}$

The foundations were laid for a strongly service-oriented pathology department. Public health work, in particular, remained a priority until 1946, when the city established its own laboratories. ${ }^{29}$ But the local hospitals, too, offered a source of income and support for the young Medical Faculty, and were carefully courted. The hospitals' routine bacteriological, histological and post-mortem work was gradually brought into the pathology department and in 1908 the professor was made ex officio honorary pathologist to the two local voluntary general hospitals. ${ }^{30} \mathrm{~A}$ similar orientation towards service work was subsequently adopted in the physiology department. The first full-time physiology teachers in the School were specialists in fields which did not readily lend themselves to routine service work. ${ }^{31}$ But in 1915 a chemical physiologist, J. B. Leathes, was appointed to the chair. Leathes had previously worked in Toronto, where he had organized clinical laboratories on the wards of the General Hospital, and he was able to offer clinicians a variety of chemical services, which resulted, in 1919, in his appointment as honorary physiologist to the Sheffield voluntary hospitals. ${ }^{32}$

This orientation towards service work meant that the Sheffield pre-clinical science departments developed a rather different character from corresponding departments in some wealthier medical schools. At the time, the Sheffield pathologists were occasionally criticized by colleagues elsewhere for neglecting what some considered to be their proper aim of establishing independent academic careers. ${ }^{33}$ Likewise,

med. J., 1936, ii: 1337-8. On tuberculosis notification schemes, see Linda Bryder, Below the magic mountain: a social history of tuberculosis in twentieth-century Britain, Oxford University Press, 1988, pp. 41-2; F. B. Smith, The retreat of tuberculosis 1850-1950, London, Croom Helm, 1988, pp. 68-9.

${ }^{28}$ Chapman, op. cit., note 22 above, pp. 157-8, 228-9; Hall, op. cit., note 21 above, pp. 42-6, 52-3. Though Robertson lectured only part-time in bacteriology, he had a full-time assistant from 1899, and a full-time lectureship was created when Robertson left Sheffield in 1903. In 1906 this post was combined with the part-time lectureship in pathology to create a single full-time professorship, held successively by: Louis Cobbett (1906-7), J. M. Beattie (1907-12), H. R. Dean (1912-15), and J. S. C. Douglas (1915-31).

${ }^{29}$ Chapman, op. cit., note 22 above, p. 426 . Douglas, in particular, was responsible for taking on the bacteriological testing required by the city under the Venereal Diseases Act of 1916, and for presiding over both a steady increase in the volume of tests performed for the local health authority, and a corresponding expansion of staff: see Medical Faculty Minutes, 31 August 1916, 2 October 1919. (The bound volumes of Medical Faculty Minutes referred to in this paper are held in SUA 8/5.)

30 This was attributed to the "tact and efficiency" of Beattie, who "won the confidence and goodwill of the various Hospital staffs, so that in course of time all their pathological work, whether in the post-mortem rooms or in the laboratory, was put under his charge": Hall, op. cit. note 21 above, pp. 60, 61. Dean later secured the routine pathological work of the South Yorkshire Asylum, for which an additional demonstrator was appointed to the pathology department: see Medical Faculty Minutes, 22 June 1914.

31 J. S. Macdonald, who came to the physiology chair from Liverpool University in November 1902, worked chiefly on nerve and muscle physiology: see H. S. Raper, 'John Smyth Macdonald 1867-1941', Obit. Not. Fellows Roy. Soc. Lond., 1939-41, 3: 853-66.

32 Rudolph Peters, 'John Beresford Leathes 1864-1956', Biog. Mem. Fellows Roy. Soc., 1958, 4: 185-91. Medical Faculty, Annual Report, 1919-1920, copy in SUA 5/1/135.

${ }^{33}$ Douglas, for instance, was criticized for running "a department which did diagnosis as well as teaching and hospital work", and for being "an over conscientious dean of the medical school": A. E. B[oycott], 'James Sholto Cameron Douglas 1879-1931', J. Path. Bact., 1932, 35: 135-6, on p. 136. On Boycott's own 
physiologists in more élite medical schools commonly regarded the kind of chemical physiology that developed in Sheffield as a poor relation of fields like nerve and muscle physiology. ${ }^{34}$ Such sentiments seem to have been shared by some of the scientists who passed through the Sheffield School on their way to more prestigious posts in London and Cambridge. ${ }^{35}$ But we should not therefore assume that medical science developed as it did in Sheffield simply for reasons of financial exigency, or that the scientists involved were thereby prevented from following careers they would otherwise have preferred. ${ }^{36}$ On the contrary, while some, especially in the older élite universities, might prefer to stand aloof from the concerns of medical practice, there is good reason to suppose that those who chose to spend substantial portions of their careers in Sheffield did so because they actually favoured the practical orientation of the programme that was taking shape there. It is thus as appropriate to ask what opportunities a city like Sheffield offered for the development of medical science as to ask what constraints it imposed.

Sheffield University should be seen as providing an institutional focus for the managerial and administrative interests that became increasingly influential in the city with the rise of large-scale industry and the growth of local government. Like other civic universities, it offered a combination of professional training and technical service work that did much to help consolidate these interests. ${ }^{37}$ The medical scientists who built their careers in Sheffield at this time saw their work as a contribution to this project. ${ }^{38}$ As such, they were not concerned with maintaining the academic purity of

refusal "to display a practical interest in the application of pathology to the everyday problems of clinical work" at Manchester University and University College, London, see C. J. Martin, 'Arthur Edwin Boycott 1877-1938', Obit. Not. Fellows Roy. Soc. Lond., 1936-38, 2: 561-71. For a study of similar tensions within a single medical school, see Robert E. Kohler, 'Bacterial physiology: the medical context', Bull. Hist. Med., 1985, 59: 54-74.

${ }^{34}$ This was the line taken in Oxford in the 1890 s by J. S. Burdon Sanderson, for instance, who attempted to move the predominantly chemical physiological work undertaken by his nephew, J. S. Haldane, from the physiology to the pathology department: see Steven W. Sturdy, 'A co-ordinated whole: the life and work of John Scott Haldane', Ph.D. thesis, University of Edinburgh, 1987, pp. 251-5. And as late as 1918, while planning an extension of his department in Edinburgh, E. A. Schäfer drew a distinction between histology and chemical physiology on the one hand, and "Physiology proper or Experimental Physiology" on the other: see Schäfer to Sir L. J. Grant and Professor Hudson Beare, 30 October 1918, in Edinburgh University Library, Special Collections Department, Gen. 2007/5.

${ }^{35}$ Myers Ward stayed in Sheffield only from 1898 to 1902 , when he moved to the Charing Cross Hospital Medical School. Likewise, the full-time professor of pathology, Louis Cobbett, appears to have "found the routine work of a laboratory, the making of autopsies and the teaching of students, rather irksome", and had been in Sheffield less than a year when he answered "the call of Cambridge": Hall, op. cit., note 21 above, p. 59.

36 The assumption that scientists naturally seek to emancipate themselves from the demands of practical application pervades much work in the history of scientific disciplines. A useful critique of this implicit teleology is Keith Vernon, 'Pus, sewage, beer and milk: microbiology in Britain, 1870-1940', Hist. Sci., 1990, 28: 289-325.

${ }^{37}$ W. H. G. Armytage described the civic universities as "community service stations": see his Civic universities: aspects of a British tradition, London, Ernest Benn Ltd., 1955. For a more sophisticated discussion of the complex role played by the civic universities see David R. Jones, The origins of civic universities: Manchester, Leeds and Liverpool, London, Routledge, 1988.

${ }^{38}$ Macdonald, in particular, was a keen advocate of the new civic universities, and he "used to say that it was only when he found himself [in Liverpool] ... with a group of men who were trying to turn the University College into a University, that he began to realize what a university really was": Raper, op. cit., note 31 above, p. 854. He used his Liverpool experience to advance the Sheffield bid for an independent university charter: Hall, op. cit., note 21 above, pp. 50-1, 64-5. 
their individual disciplines so much as with developing lines of research and teaching that would be of direct use to other institutions in the city. The University pathologists, for instance, argued that contact with clinical practice was crucial for the development of their science, and that service work for local hospitals was essential to this process. ${ }^{39}$ Bacteriological testing for the local public health authority was seen to offer similar scientific opportunities. ${ }^{40}$

More than this, however, such work also enabled the University's full-time scientists to take an influential role in shaping new administrative and managerial responses to problems of public health. Occupational illness, in particular, was early identified as a problem that university scientists might usefully investigate, and it provided a focus of continuing interest for the staff of the pathology department. ${ }^{41}$ Members of the physiology department extended this programme by looking also at industrial fatigue. ${ }^{42}$ Work of this kind tied the Medical School into the local economy in new ways. Where previously the School had served simply to train the doctors who would practise in the region, it was now closely involved in the work of local government, industry, and the hospitals. In effect, the scientific staff of the Medical School, like scientists in other faculties of the new University, were becoming integrated into an administrative élite that was increasingly indispensable to the running of the city.

\footnotetext{
39 In 1910, Beattie told the Nottingham division of the British Medical Association that "the pathologist who neglects the post mortem room or even the bedside cannot fully realize the greatest problems of disease. In his work, therefore, he must be assisted by the clinician, and in their hearty co-operation . . . the advance in scientific medicine must be greatly aided": J. M. Beattie, "An address on the activity of the cells and fluids of the body in the prevention and cure of disease: a plea for more thorough pathological investigation', Brit. med. J., 1910, i: 977-9, on p. 979. Dean likewise denied that pathology was "an independent science - such as some would make of physiology-a specialised department of biology standing proudly aloof from the crafts of medicine and surgery", and he added that "just as a knowledge of medicine must be based in part on the experience of the post-mortem room, so is a knowledge of pathology incomplete without the study of the manifestations of disease in living patients in the ward": Henry R. Dean, 'Pathology and the medical student', Edin. med. J., 1918, N.S., 20: 307-18, on pp. 307, 308. Dean was particularly interested in syphilis as a cause of insanity, and this evidently motivated his efforts to secure the pathological work of the South Yorkshire Asylum: see H. R. Dean, 'Idiocy and congenital syphilis', Brit. J. Child. Dis., 1912, 9: 385-96, and his request for research funds in Medical Faculty Minutes, 22 June 1914.

${ }^{40}$ When, in 1913, an appeal for research funds was made to the Home Office Committee on Tuberculosis, it was stressed that the local notification scheme had already "afforded such valuable data for information": Sheffield University to Departmental Committee on Tuberculosis, 14 February 1913, SUA 5/1/26, ff. 337-8. In similar vein, Douglas later argued that routine testing under the Venereal Diseases Act of 1916 should be performed in the pathology department "not only in the public interest, but also for the opportunities presented for study and the extension of knowledge on this subject": Medical Faculty Minutes, 31 August 1916.

${ }^{41}$ The possibility of investigating local trade diseases was first used as an argument in favour of creating a university medical faculty in Sheffield: see the 1903 report of the Board of Medical Studies to the Senate on 'The requirements for forming a medical faculty of a university', SUA 5/1/26, ff. 28-38, on f. 37. Beattie was particularly active in pursuing such work: J. M. Beattie, 'Hygiene of the steel trade', J. Roy. San. Inst., 1912, 33: 501-5; and W. Harwood Nutt, J. M. Beattie and R. J. Pye Smith, 'Arsenic cancer: a case: a pathological report on the parts removed: together with summaries of 39 other collected cases, and remarks', Lancet, 1913, ii: 210-16, 282-4.

${ }^{42}$ Macdonald was involved in developing such research both locally and nationally through the British Association for the Advancement of Science. See: J. S. Macdonald, 'Calorimetric observation on man', $J$. Physiol., 1912, 44: iv-vP; idem, 'Studies in the heat production associated with muscular work. (Preliminary communication: Section A.-Methods; Section B.-Results.)', Proc. Roy. Soc. B, 1913, 87: 96-112; idem, 'Mechanical efficiency of man', J. Physiol., 1914, 48: xxxiiP; idem, 'Man's mechanical
} 


\section{SCIENCE AND THE STRUCTURE OF MEDICAL PRACTICE}

The establishment of the laboratory sciences in the Sheffield Medical School was dependent on the support of at least some of the medical practitioners who taught there, and this support continued to be important in shaping the scientific programme that developed over the next twenty years. Clinical involvement, in particular, contributed to the growth of a practically-oriented rather than a purely academic style of research and teaching in the pre-clinical departments. Conversely, for those practitioners who participated in this programme, the development of medical science offered a way of encouraging the establishment of new forms of medical practice in Sheffield.

From its beginnings in the first half of the nineteenth century, the Medical School had helped to structure practice in the city. Initially, it served what Ian Inkster has called an "identity forming function" for the local medical profession: it provided an institutional base around which doctors could organize, not least to regulate recruitment to the ranks of recognized practitioners; and it gave the doctors who taught there a platform from which to advertise their knowledge and skills to students, to other doctors, and to their prospective patients. ${ }^{43}$ By mid-century, the School had come to serve the interests of a well-established élite, dominated by doctors with surgical qualifications, whose part-time teaching had also helped them to establish successful careers in the voluntary hospitals and in private practice. ${ }^{44}$

The reputation of these élite doctors rested primarily on their skills and attainments in the practice of medicine and surgery, and the greatest prestige consequently attached to the School's clinical lectureships. But clinical achievements were also seen to be at least partly rooted in scientific knowledge, and especially, in the case of surgery, in anatomical skills. ${ }^{45}$ Anatomy teaching was thus central to the work of the mid-century Medical School: it provided students with a scientific preliminary to clinical training, and teachers with a stepping stone to more prestigious clinical teaching posts. And when the fortunes of the School began to decline in the second half of the century, the staff looked first to the expansion of anatomy as a way of reviving the School's scientific reputation. By 1890 a huge new anatomy theatre,

efficiency in work performance and the cost of the movements involved (treated separately)', Proc. Roy. Soc. B, 1916, 89: 394-410. On the national context of Macdonald's research, see: Richard Gillespie, 'Industrial fatigue and the discipline of physiology', in Geison (ed.), op. cit., note 9 above, pp. 237-62; A. J. McIvor, 'Manual work, technology, and industrial health, 1918-39', Med. Hist., 1987, 31: 160-89.

${ }^{43}$ Inkster, op. cit., note 11 above, p. 142; cf. S. W. F. Holloway, 'Medical education in England, 1830-1858: a sociological analysis', History, 1964, 49: 299-324.

${ }^{44}$ Chapman lists the qualifications of 64 of the men who taught in the Medical School between 1844 and 1897. Of these, 14 held approximately equal qualifications in medicine and surgery; 37 were primarily qualified in surgery, usually with a lesser diploma in medicine ( 31 of these were Licentiates of the Society of Apothecaries); and 17 had primarily medical qualifications. Between them, they also held 51 voluntary hospital or dispensary appointments (some doctors held more than one appointment), while six were Poor Law Medical Officers and three were Medical Officers of Health to the city. Chapman, op. cit., note 22 above, pp. 474-8.

45 The relationship between the rise of anatomy teaching and the emergence of a discourse of medical skill in the late eighteenth and early nineteenth century remains sadly under-studied. But see M. E. Fissell, Patients, power and the poor in eighteenth century Bristol, Cambridge University Press, 1991, which explores some of these issues. Cf. Christopher Lawrence, 'Alexander Monro primus and the Edinburgh manner of anatomy', Bull. Hist. Med., 1988, 62: 193-214. 
capable of seating over a hundred students, was in an advanced stage of construction. ${ }^{46}$

It took a younger generation of doctors to make the case for building up the new laboratory sciences as well. The moving force behind this reorientation was Arthur Hall, a physician and a skilful medical politician who, more than any other, was responsible for the reform of the Medical School. ${ }^{47}$ The son of a successful Sheffield general practitioner, Hall had begun medical studies at the Sheffield School in 1883, but found the teaching so unsatisfactory that he promptly moved on to Cambridge University for pre-clinical studies, then to St Bartholomew's Hospital in London for clinical training. In 1889 he returned to work in his father's practice, but he was not content merely to assume his father's mantle. Within the year he was teaching at the Medical School as a part-time demonstrator in physiology, and quickly became involved in plans to collaborate with the other local colleges of higher education, and in the campaign for an independent university. In particular, with his experience of the new physiology laboratories in Cambridge, Hall was well aware of the latest trends in pre-clinical science teaching, and he was in large part responsible for persuading his elders that the scientific focus of the School must shift from anatomy to physiology and pathology if it was to survive in competition with medical schools elsewhere. ${ }^{48}$ Hall himself helped design the necessary laboratories, and he taught the physiology and pathology courses until funds became available for full-time professors. ${ }^{49}$

Hall was not concerned simply to save the School, however, nor was he motivated purely by a desire to emulate the academic science he had met at Cambridge. He also saw the promotion of laboratory science as a way of reforming medical practice. In London, leading doctors like those who had taught Hall on the wards at Bart's relied increasingly on consulting practice for their very considerable incomes. This consulting practice represented a new division of medical labour: it involved a measure of specialization on the part of consultants, who restricted their practices to either medical or surgical cases; and it depended on a network of intra-professional communication which linked consultants to the general practitioners from whom they received their patients. ${ }^{50}$ In Sheffield, however, this systematic division of labour

\footnotetext{
${ }^{46}$ Hall, op. cit., note 21 above, p. 15. The doctors most closely identified with the Medical School at this stage, and with the efforts to regenerate it through anatomy teaching, were the surgeons Arthur Jackson and William Favell, and the physician W. Tusting Cocking. See their obituaries in, respectively: Brit. med. J., 1896, i: 117-18; ibid., 1896, ii: 1418; ibid., 1912, ii: 1169.

47 [Robert] Platt, 'Hall, Sir Arthur John (1866-1951)', DNB 1951-1960, 451-2; A. Gurney Yates, 'Sir Arthur J. Hall', Sheffield University Gazette, February 1951, No. 10, pp. 2-4.

${ }^{48} \mathrm{He}$ met resistance, for instance, from Arthur Jackson, who was adamant that "The school shall stand or fall by its anatomy theatre": Hall, op. cit., note 21 above, p. 15 . In fact, the first full-time teaching post to be created in the School, in 1894, was in anatomy; the incumbent was Christopher Addison, later to become Britain's first Minister of Health: DNB 1951-1960, pp. 3-7.

${ }^{49}$ Yates, op. cit., note 47 above, p. 2.

50 Consultants began to distinguish themselves from general practitioners during the first half of the nineteenth century, but this was primarily a matter of social stratification and higher fees, rather than a system of intra-professional referral and consultation. By the 1880 s the British Medical Association had begun to call for a clearer division of labour, but this was hindered by general practitioners' fears that consultants would steal the patients referred to them. Only in the metropolis and in the largest provincial cities like Manchester were a few leading doctors able to live chiefly by consulting practice. See Ivan
} 
remained rudimentary throughout the nineteenth century; even the most eminent of the Medical School doctors continued to be primarily general practitioners, who relied less on referrals from other members of the profession than on the close personal relationships they established with their individual patients. ${ }^{51}$

Hall's ambition was to establish his own consulting practice in the city, and he saw the reform of the Medical School as a step towards fulfilling that ambition. ${ }^{52}$ The development of the new experimental sciences, in particular, was central to this plan. Among the eminent consultants who had taught him in London were some whose reputations were based, not just on their clinical attainments and their reputations as teachers, but also on the contributions they had made to the new experimental sciences. Hall chose to emulate these doctors by conducting his own scientific studies of illness and its treatment. ${ }^{53}$ His efforts to build new laboratories and to employ full-time scientists were thus motivated, at least in part, by the need for scientific facilities that would enable him to pursue his own work, and he would subsequently rely heavily on the pathology department, in particular, for help in investigating some of the clinical problems he encountered in the course of his practice ${ }^{54}$ His example was soon followed by other aspiring young Sheffield doctors, physicians and surgeons alike, who shared his view that research as well as teaching would help to further their careers, and who likewise looked to the Medical School's scientific staff for assistance in such work. ${ }^{55}$

Waddington, The medical profession in the industrial revolution, Dublin, Gill and Macmillan, 1984, pp. 9-18; idem, 'General practitioners and consultants in early nineteenth-century England: the sociology of an intra-professional conflict', in Woodward and Richards (eds), op. cit., note 11 above, pp. 164-88; M. Jeanne Peterson, The medical profession in mid-Victorian London, Berkeley, University of California Press, 1978, pp. 227-31, 272-3; Rosemary Stevens, Medical practice in modern England: the impact of specialization and state medicine, New Haven and London, Yale University Press, 1966, pp. 31-4.

51 Thus Hall wrote of William Favell: "although, no doubt, a man of wide experience and shrewd common-sense, he was more of a welcome and comforting general practitioner, whose patients worshipped him, than what is meant by a Surgeon today." And of Arthur Jackson: "it is doubtful whether he ever did much [surgery] in private practice, for there were no surgical specialists in Sheffield in his days; they were all general practitioners." Hall, op. cit., note 21 above, pp. 6, 14.

52 As he later put it, he was "determined to start as a physician in Sheffield and not to continue in [his] father's general practice". He regarded the Medical School as an "asset of primary importance" in the career of "a would-be physician", and he added: "Whatever small amount of time and trouble our school may have had from me, it has been more than repaid by the value it has been to me during the 42 years that I was on its staff'. Hall, op. cit., note 21 above, pp. 28-9.

${ }^{53}$ Hall's ideal of the physician-scientist may well have been personified in Thomas Lauder Brunton, "the most widely known consulting physician in London" and "one of the founders of modern pharmacology", who taught at Bart's while Hall was a student there. J. A. G[unn], 'Brunton, Sir Thomas Lauder', DNB, 1912-21, pp. 75-6; and on Brunton's pharmacological work, see William F. Bynum, 'Brunton, Thomas Lauder', DSB, Vol. II, pp. 547-8. Hall himself identified pharmacology as one of the fields of laboratory science which would most benefit medical practice, and he went on to conduct his own clinical studies of the effects of new drugs, including secretin and thyroid extract which had their origins in the physiological laboratory. See Arthur J. Hall, 'Case of sporadic cretinism, in which a relapse occurred owing to omission of thyroid extract', Brit. med. J., 1902, i: 1259-61; and idem, 'Clinical observations on the effects of certain drugs in diabetes mellitus', $Q$. J. Med., 1908-9, 2: 417-31.

54 Beattie, in particular, was keen to collaborate in this kind of work. See J. M. Beattie and A. J. Hall, 'An unusual chronic interstitial pneumonia (diffuse bilateral pulmonary fibrosis) following(?) influenza', Edin. med. J., 1910, 5: 199-207; Beattie and Hall, 'A fatal case of secondary syphilitic nephritis: with remark', Brit. med. J., 1911, i: 1102-4.

55 One such was A. G. Yates, who joined Beattie in studying the bacteriology of rheumatism: J. M. Beattie and A. G. Yates, 'Sugar tests and pathogenicity in the differentiation of streptococci', J. Path. Bact., 


\section{Steve Sturdy}

By the end of the First World War, this kind of scientific research was helping the Medical School clinicians, like the full-time laboratory scientists, to adopt a new and highly visible role in the medical life of the city. This is most obvious in relation to the development of public health medicine, where the full-time pathologists were already active. Clinical studies of trade diseases, in particular, enabled Hall and his colleagues to stake a claim as medical experts in this field. ${ }^{56}$ By 1918 , Hall was working with the Home Office to establish a local compensation scheme for workers killed or disabled by silicosis. Under this scheme, Hall and A. E. Barnes were appointed to a Medical Advisory Committee charged with the delicate and potentially controversial task of diagnosing any doubtful cases referred to them by Medical Officers. ${ }^{57}$ Six years later, a severe outbreak of encephalitis lethargica provided an opportunity to extend this role as expert advisors to include other public health problems. Their extensive and detailed collaborative study of the epidemic, involving both laboratory and clinical investigations, prompted the local division of the British Medical Association and the Medical Officer of Health to join in appointing a Local Medical Advisory Committee, including Hall and other members of the Medical Faculty, "whose advice and assistance would be available to the health authority, either in the event of other epidemic outbreaks, or in any matter affecting the public health". 58 In effect, the clinical teachers had joined their full-time colleagues as consultants to whom the local health authority could turn for definitive judgments on problems of public health practice.

At the same time, closely related developments were taking shape in private medical practice. Hall's work on encephalitis, for instance, earned him a reputation as

1911-12, 16: 247-56; idem, 'Bateriological examination of the synovial membrane from the knee-joints in eighty-five consecutive post-mortems', J. Path. Bact., 1911-12, 16: 404-5; idem, 'The variations in the morphological characters of bacteria and their reaction with sugars under different conditions', Brit. med. J., 1912, ii: 1304-5; idem, 'The streptococcus in rheumatism', J. Path. Bact., 1912-13, 17: 416-18. Another was the surgeon, R. J. Pye Smith, who collaborated with Beattie and W. Harwood Nutt, Medical Officer to the Sheffield Union Workhouse and Honorary MO to the X-ray department at the Royal Hospital, in a study of a local trade disease: Nutt, Beattie and Pye Smith, op. cit., note 41 above.

56 Hall, like Pye Smith, had taken an early interest in the clinical aspects of occupational diseases. See Arthur Hall, 'Some remarks on forms of trade dermatitis occurring in the silver and electro-plating trades', Br. J. Derm., 1902, 14: 121-6. And see, in particular, the 'Discussion on diseases of the lungs caused by dust', Brit. med. J., 1908, ii: 480-5, in which Harold Scurfield (MOH for Sheffield and professor of public health in the University) and A. E. Barnes took opposing views of the aetiology of such diseases, but concurred in emphasizing the managerial and administrative advantages that they believed would be gained by scientific and clinical research in this field.

${ }^{57}$ At Hall's suggestion, the Home Office had asked the Medical Faculty to nominate "two representatives specially qualified by their clinical experience", bearing in mind that "It is of the utmost importance to the working of this scheme that this Committee ... should be a strong one": Home Office to Medical Faculty, 18 November 1918, letter appended to Medical Faculty Minutes, 25 November 1918 . Hall and Barnes were duly nominated to serve along with Harold Scurfield, appointed by the Home Office in his capacity as MOH. This compensation scheme, embodied in the Workmen's Compensation (Refractories Industry) Act 1919, was the first to be set up within a specific industry, in this case the refractories industry, which made fire bricks to line blast furnaces: Arnold Wilson and Hermann Levy, Workmen's compensation, vol. 1, Social and political development, London, Oxford University Press, 1939, pp. 174, 263-5.

${ }^{58}$ British Medical Journal, 'Sheffield Local Medical Advisory Committee', Brit. med. J., 1924, ii: 1132. The Committee went on to investigate a number of health problems in the city, including breast cancer. The encephalitis work was published as The Sheffield outbreak of epidemic encephalitis in 1924, MRC Special Report series No. 108 (1926), and included the work of Wynne on the epidemiology of the disease, Hall and Yates on the clinical aspects, and Douglas on the pathology. 
"an authority of international standing" on the treatment as well as the public health aspects of the disease, and laid the cornerstone of a highly successful consulting practice. ${ }^{59}$ As in public health work, scientific research was now increasingly seen as a criterion of expertise in private practice. This was reinforced by the highly visible involvement of University doctors as consultants to the local public health authority, which served both to advertise their expertise and to set a precedent for individual consultations. By this time, as one Sheffield physician recalled, "The concept of the pure Consultant was taking shape and a younger generation was arising, ambitious to achieve Consultant status". ${ }^{60}$ But the institutionalization of this new division of medical labour in the city cannot be separated from the rise of the University as a civic centre of technical, administrative and above all scientific expertise. By promoting the growth of the University through their educational, investigative and administrative activities, Hall and other scientifically-inclined clinicians thus defined for themselves a new role as experts in both the private and public practice of medicine, to whom both the local health authority and local general practitioners could turn for authoritative assistance in difficult cases.

\section{THE MEDICAL SCHOOL AND THE REFORM OF THE HOSPITALS}

Not all Sheffield doctors were equally enthusiastic about this restructuring of medical practice, however. Those men who constituted the élite of the local profession in the years before the First World War had made their careers primarily as general practitioners to the city's wealthier classes, and they were deeply ambivalent about the emergence of consulting practice, and especially about the relatively specialized forms of scientific knowledge around which it was organized. This was particularly evident in the two local voluntary general hospitals. Founded in 1797 and 1832 respectively, the Royal Infirmary and the Royal Hospital had initially served much the same professional interests as the Medical School. ${ }^{61}$ As a focus of philanthropic activity in the newly industrializing city, they not only provided an institutional base for the emerging medical élite, but also brought the honorary physicians and surgeons into direct personal contact with the wealthy patrons among whom they sought their private patients. ${ }^{62}$ Moreover, they were closely involved with the Medical School in the development of a local system of medical education: not only was the clinical

\footnotetext{
59 Platt, op. cit., note 47 above, p. 451 . Though he retired from the staff of the Royal Infirmary in 1931, Hall continued to run a weekly encephalitis clinic there until his death: see obituary, Sheffield Telegraph, 4 January 1951.

${ }^{60}$ A. G. Y[ates], 'Great teachers of surgery in the past: Sir Ernest Finch (1884-1960)', Br. J. Surg., 1965, 52: $81-4$, on p. 83. Others of this generation who came to dominate the Sheffield medical profession in the inter-war years included A. G. Yates himself (obituary, in Gordon Wolstenholme (ed.), Munk's roll, vol. 7, Lives of the Fellows of the Royal College of Physicians of London continued to 1983, Oxford, IRL Press, 1984, pp. 627-8), A. E. Barnes (obituary, Brit. med. J., 1956, ii: 1060-1), and A. E. Naish (obituary, in Gordon Wolstenholme (ed.), Munk's roll, vol. 5, Oxford, IRL Press, 1965, pp. 302-3).

61 John D. Leader and Simeon Snell, Sheffield Royal Infirmary 1797-1897, Sheffield, published on behalf of the Infirmary Board, 1897; E. F. Skinner, A short history of the Sheffield Royal Hospital, 1832-1932, Sheffield, Greenup \& Thompson, 1932.

62 On the role of the hospitals in the identification of élite practitioners in Britain generally at this time, see: Waddington, The medical profession, op. cit., note 50 above, pp. 26-8, 30f; Jeanne Peterson, op. cit., note 50 above, pp. 138-51; John Woodward, To do the sick no harm: a study of the British voluntary hospital system to 1875, London, Routledge \& Kegan Paul, 1974, pp. 23-6.
} 


\section{Steve Sturdy}

teaching carried out on the wards of the hospitals, but also, prior to the establishment of full-time professorships, the pre-clinical teaching was conducted by members of the hospital staffs.

With the growth of the new laboratory sciences in the last quarter of the nineteenth century, however, this community of interest began to fracture. By the 1880 s, there was growing pressure to emulate medical schools elsewhere in Britain by placing large parts of the pre-clinical curriculum in the hands of full-time professional scientists. This pressure for reform did not extend to the clinical teaching, however. In Britain as a whole, the quality of clinical education tended to be judged chiefly by the size of the teaching hospital and the range of practical experience that the student could expect to acquire there. On these criteria, Sheffield was able to compete relatively successfully with other British clinical schools. ${ }^{63}$ Thus, while a few clinicians led by Arthur Hall welcomed the introduction of new forms of science into the Sheffield Medical School, the majority remained at best indifferent, while many appear to have been openly suspicious. The result was a growing divergence of interest between the hospitals and the Medical School, and a deepening division between pre-clinical and clinical teaching in the city.

As early as 1882, the clinical teachers established their own Clinical Studies Committee, quite independent of the Medical School, which took responsibility for all the educational work conducted in the Sheffield hospitals. ${ }^{64}$ The formation of the University Medical Faculty in 1905 left the Clinical Studies Committee intact and independent, while the creation of a number of part-time clinical professorships ensured that clinicians were well represented in the University, and so were in a strong position to resist any encroachment on their autonomy. This became clear between 1909 and 1911, when the central government Board of Education introduced measures which were intended to enforce greater university control of clinical teaching in medical schools throughout the country. The Sheffield clinicians vigorously resisted this imposition, and in the end were able to force a compromise solution which left them in effective control of the clinical fees and the organization of bedside teaching. ${ }^{65}$

${ }^{63}$ Indeed, association with the large provincial infirmaries was a positive selling point for academically less prestigious medical schools like Sheffield, and was stressed, for instance, in the 1903 report on 'The requirements for forming a medical faculty of a university', op. cit., note 41 above, f. 37. Cf. Stella V. F. Butler, 'Centers and peripheries: the development of British physiology, 1870-1914', J. Hist. Biol., 1988, 21: 473-500.

${ }^{64}$ Porter, op. cit., note 20 above, pp. 97-100. The Committee assigned students to tutors for their work in the hospitals, and collected and distributed the fees among the clinical lecturers and tutors. It is not clear whether this split from the Medical School, which took place in the context of debate over the reform or possible closure of the School, was intended primarily as a defence of clinical autonomy, or simply as a way of preserving the educational role of the hospitals in the event of closure.

${ }^{65}$ In 1909 the Board of Education announced a system of government grants in support of technical education, including medical teaching. The Sheffield Medical Faculty applied, but was turned down on the grounds that the Faculty was not responsible for the activities of the clinical teachers. The compromise solution was formally to disband the Clinical Studies Committee and reconvene it as a sub-committee of the University Council. The Board accepted this manoeuvre with the assurance that there was already a majority of Faculty members on the Committee, and that the University Registrar would ensure that Faculty members always made up at least half of the Clinical Studies Committee. In 1910, however, these Faculty members were almost exclusively part-time clinical teachers, and did not represent the majority view of the Faculty, to which the Committee still had no formal responsibility. The lengthy correspondence 
Despite this tension, however, the hospitals continued to give a limited degree of support to the programme of medical science that was developing in the Medical School. To a considerable extent this support was due to the advocacy of Arthur Hall, whose career spanned the gap between the different institutions. From the beginning, Hall divided his time between building up the scientific work of the Medical School and pursuing a career as a clinician. In 1890 he obtained a post as assistant physician to the Royal Hospital, and from 1892 to 1910 he served as secretary and treasurer of the Clinical Studies Committee. ${ }^{66} \mathrm{He}$ was successful in winning the confidence of the hospital staffs, particularly as a medical educationalist, and he used this influence to secure clinicians' support for the development of the new pre-clinical laboratory sciences. $^{67}$

As I have already argued, however, Hall's ambitions did not simply revolve around the reform of pre-clinical science in Sheffield. He also sought to restructure medical practice around new forms of scientific authority, in ways that many of his clinical colleagues distrusted. The scientific programme that he fostered in the Medical School was carefully tailored to fit this aim. Rather than provoke a direct clash of interests between pre-clinical and clinical teachers of the kind that the Board of Education seemed to favour, Hall chose instead to introduce full-time scientists into the hospitals gradually, initially by developing forms of service work, particularly in pathology, which could be seen as reinforcing rather than undermining clinicians' own judgments. ${ }^{68}$ But this co-operation between clinicians and full-time scientists also facilitated the transfer of important sections of what was commonly regarded as the clinical curriculum into the laboratories of the Medical School.

The development of a laboratory-based science of pharmacology was particularly important in this respect. Prior to the establishment of Sheffield University, therapeutics and materia medica were seen very much as clinical subjects, to be taught by practising clinicians. Hall voiced a rather different point of view. At the bedside as in the laboratory, he argued, pharmacology was a science, albeit a less exact one than experimental physiology or pathology, and it depended on different methods of observation from those that clinicians had previously employed in the course of their routine practice. ${ }^{69}$ On these grounds, it ought to be brought under the control of

over this issue is held in SUA 5/1/26, ff. 99-322, and see especially the letter from W. M. Gibbons to H. Frank Heath, 17 February 1911, at f. 243.

${ }^{66}$ Porter, op. cit., note 20 above, p. 100.

${ }^{67}$ Hall claimed to have been instrumental in convincing the older surgeons that they should divert resources from the new anatomy theatre to build laboratories, in persuading the hospitals to donate their pathology teaching collections to the School, and in securing an annual grant from the Clinical Studies Committee to maintain those collections. Arthur Hall, op. cit., note 21 above, pp. 30-1, 38. As secretary and treasurer of the Clinical Studies Committee he was also presumably instrumental in reaching a compromise solution that left clinicians in charge of the clinical teaching but also left open the possiblity of future University influence. When he resigned from this post on the Committee in 1910, he was replaced by J. M. Beattie, who was by this time conducting the hospitals' routine diagnostic work.

${ }^{68}$ For a detailed discussion of the subordinate relationship of the pathological laboratory to bedside diagnosis in one hospital at this time, see Jacyna, op. cit., note 8 above.

69 "Prolonged clinical observations on the effects of drugs in disease can never be carried out in the exact manner that is possible in laboratories where the lower animals are kept under observation," said Hall, "but provided this fact is constantly kept before us, they have a certain value of their own which the 


\section{Steve Sturdy}

full-time scientists. Thus as early as 1903, Hall included a full-time chair of pharmacology and chemical physiology in his outline of the requirements for a university medical faculty, ${ }^{70}$ but the post had to be shelved for lack of funds. Over the next decade, however, he was able gradually to allocate the greater part of the old course in therapeutics to teachers in the physiology department. ${ }^{71}$

Meanwhile, similar developments were taking place in the pathology department. As a result of the histological, bacteriological and post-mortem service work that it undertook for various hospitals in the region, the department had managed to maintain a relatively close relationship with clinicians, and in 1908 the professor of pathology was appointed ex officio honorary pathologist to the two voluntary hospitals. ${ }^{72}$ But in 1910, prompted by the highly publicized success of vaccine therapy, the Sheffield University pathologists began to develop an interest in chemical pathology and immunology. ${ }^{73}$ This new line of work was greeted with ambivalence by local clinicians. Where earlier forms of diagnostic service work had tended to reinforce rather than challenge doctors' own clinical judgments, the highly technical procedures of vaccine therapy now threatened to remove responsibility for therapeutic decisions from the bedside to the laboratory. Hall and his sympathizers were eventually able to overcome this ambivalence, but only with difficulty: when, in 1912, the pathology chair fell vacant, vigorous canvassing was necessary before the clinicians would assent to the appointment of H. R. Dean, whose reputation lay in "the difficult and rather obscure field of immunology" ${ }^{74}$

artificial circumstances of a laboratory experiment cannot have." Hall, 'Clinical observations', op. cit., note 53 above, pp. 417-18.

${ }^{70}$ Report on 'The requirements for forming a medical faculty of a university', op. cit., note 41 above.

${ }^{71}$ By 1908 the professor of physiology was running a practical course in pharmacology. In $1911 \mathrm{~W}$. T. Cocking retired from the part-time chair of materia medica, pharmacology and therapeutics, and the Faculty appointed a sub-committee to consider a rearrangement of the course. Besides Macdonald and W. P. Wynne (professor of chemistry) for the full-time scientific staff, the committee included Hall, Naish and Barnes for the clinical teachers: both Naish and Barnes were younger clinicians who sympathized with Hall's views on scientific medicine. This committee recommended the appointment of a full-time lecturer in chemical physiology to replace the part-time professor of therapeutics and to teach a course in chemistry previously given by Wynne. Only the teaching of materia medica was to remain in the charge of a part-time lecturer. Macdonald subsequently distanced the new course from the old style of teaching by stressing that the new lecturer was to give "an extension of the present teaching in chemical physiology". A full-time lecturer was duly appointed in 1912. Medical Faculty Minutes, 16 October 1911, 29 January 1912, 20 May 1912; Medical Faculty, draft Annual Report, included in Medical Faculty Minutes, 26 September 1912.

72 Hall, op. cit., note 21 above, pp. 60,61 .

${ }^{73}$ In his 'Address on the activity of the cells and fluids of the body in the prevention and cure of disease', Beattie referred obliquely to the promise of vaccine therapy, and declared that "the work of Wright and his school, no matter what may be our views as to the methods employed or the deductions drawn from them . . . must be regarded as epoch making": Beattie, op. cit., note 39 above, p. 979. On the significance of vaccine therapy at this time, see Michael Worboys, "Vaccine therapy and laboratory medicine in Edwardian Britain', in J. V. Pickstone (ed.), Medical innovation in historical perspective, op. cit., note 5 above, pp. 84-103.

74 J. Henry Dible, 'Henry Roy Dean 19th February 1879-13th February 1961', J. Path. Bact., 1962, 83: 587-97, on pp. 587-8; Hall, op. cit., note 21 above, p. 65. A similar disagreement occurred in Sheffield in 1932, over the appointment of Howard Florey to succeed Douglas as professor of pathology, and again in 1935 over Florey's successor, when the Faculty had to recommend explicitly "That an experimental pathologist rather than a morbid anatomist be appointed to the Chair of Pathology": Hall, op. cit., note 21 above, p. 76; Medical Faculty Minutes, 29 April 1935. 
This cross-disciplinary programme of chemically-oriented pre-clinical science was further consolidated in 1914, when Leathes was persuaded to leave the chair of chemical pathology at Toronto University for the Sheffield physiology chair. Besides offering a variety of chemical and physiological diagnostic tests for use by Sheffield clinicians, Leathes was also keen to develop clinical laboratories for both teaching and research purposes. In this respect, he shared the views of Dean, who argued that the pathological laboratory should be used in clinical education. ${ }^{75}$ This was precisely the kind of clinical involvement that Hall and his scientific colleagues wanted to encourage, and that they now sought to make the basis of a more complete reorganization of the clinical curriculum around laboratory-based chemical studies.

Within a year, Hall had set in motion a series of manoeuvres within the Faculty that ended with his own appointment as part-time professor of medicine, and the translation of a part-time lectureship in practical medicine into "what has long been felt as wanting in the curriculum, namely a pally practical course of clinical pathology including elementary bacteriological, chemical and other methods in connection with the work in the Wards."76 While it is not clear quite what impact this course would have had on clinical teaching in Sheffield, Hall evidently intended it as a way of carrying his programme of scientific medicine into the hospitals. In the event, however, the continuing disruption of the First World War made it "difficult to carry out such a scheme efficiently and . . . better to defer any permanent change until the War is over", and the Faculty agreed that "the course should be carried on for the present year by Dr. Hall ... [with] . . . assistance from the Professors of Pathology and Physiology in those subjects requiring laboratory demonstrations." 77 And by the time the war ended, the medical politics of the city and of the country had shifted so radically that Hall could reopen his campaign of clinical reform on a far wider front than had previously been possible.

\section{DEVELOPMENTS FOLLOWING THE FIRST WORLD WAR}

The spirit of wholesale reconstruction that came with the end of the First World War placed new pressures on voluntary hospitals throughout Britain. It had long been argued that the two tier system of state-funded Poor Law infirmaries and élite voluntaries led to a wasteful duplication of services. Meanwhile, rising costs had

\footnotetext{
75 Dean argued that "accommodation, equipment and staff should be adequate for the bacteriological, chemical, and histological examination of the cases in the wards": op. cit., note 39 above, p. 315.

${ }^{76}$ Report inserted in Medical Faculty Minutes, 13 September 1915, cancellation as original. These manoeuvres were begun in the expectation that the part-time professor of medicine, Duncan Burgess, was shortly to retire. Thus in February 1915, Hall resigned the part-time lectureship in practical medicine that he had held for the past ten years. Before he did so, the Faculty agreed to postpone the election of a successor "in order that a possible rearrangement of the course might be considered". In May the Faculty appointed a committee, consisting of $\mathrm{Hall}$ and Barnes and the professors of physiology and pathology, to consider the matter further, and in September, the Faculty approved the committee's recommendation that the course be devoted to clinical pathology. And when Burgess duly vacated the professorship in medicine, Hall was appointed to the post, "there being no other candidates", to take overall charge of the medical teaching. Medical Faculty Minutes, 16 February 1915, 17 May 1915, 13 September 1915, 22 November 1915.

${ }^{77}$ Report inserted in Medical Faculty Minutes, 13 September 1915.
} 
precipitated a financial crisis in the voluntary hospitals, which were burdened with long waiting lists, but barely had the funds to maintain the existing level of services. The Poor Law hospitals, on the other hand, remained under-used because of the stigma of pauperism that attached to them. With the establishment of the Ministry of Health in 1919, it soon became apparent that the government intended to take a hand in reorganizing the hospital system. In particular, it was feared that the Ministry would seek a degree of financial and managerial control of the previously independent hospitals, with the eventual aim of bringing them into a single hospital service under municipal control. ${ }^{78}$

The provincial teaching hospitals felt themselves to be particularly at risk following the publication, in 1920, of the much-vaunted Dawson Report, which identified them as the regional hubs around which the hospital system would be reorganized. ${ }^{79}$ And in Sheffield, these fears were compounded by the existence of not one but two voluntary general hospitals, which emphasized the problems of inefficiency and duplication of services. Driven by such fears, the Sheffield hospitals sought to pre-empt state interference by undertaking their own programme of reform on their own terms. Previously, the two Sheffield voluntary hospitals had been divided by strong institutional rivalries. Now, they were compelled to accept that both the work and the funding of the different hospitals needed to be co-ordinated in the interests of greater efficiency.

A letter sent by the "Joint Medical Staffs" to the Boards of the voluntary hospitals led, in 1920, to the establishment of a Joint Consultative and Advisory Hospitals Council. ${ }^{80}$ This body proved remarkably successful in addressing the problems that were seen to beset the Sheffield hospitals. First, with the support of the local Poor Law Guardians, the Hospitals Council set up a scheme for co-ordinating admissions to the voluntary and Poor Law hospitals. Then, in 1922, a number of other civic and local government bodies joined the Hospitals Council in creating a penny-in-thepound contributory scheme, organized through local workplaces, to fund treatment in both kinds of hospital. By 1923, income from this scheme equalled the hospitals' collective costs, admissions procedures were effectively co-ordinated, and waiting lists

\footnotetext{
${ }^{78}$ In 1920, the Minister for Health introduced a Bill to permit local authorities to take over Poor Law hospitals, but the Bill was defeated, in part because it embodied the principle of state subscription to the voluntary hospitals. Similar threats to the autonomy of the voluntaries were posed by two reports commissioned by the Ministry of Health. The Dawson Report on The future provision of medical and allied services, published in 1920, proposed an enormous expansion of existing state-funded hospital facilities, with grants-in-aid to voluntary hospitals if they would co-operate in this state health service. And the 1921 Report of the Cave Committee on the financial difficulties of the voluntary hospitals proposed temporary state grants on condition that the voluntary hospitals made appropriate efforts to rationalize their services and increase their economic efficiency. See Brian Abel-Smith, The hospitals 1800-1948, London, Heinemann, 1964, pp. 299-300, and passim.

${ }^{79}$ Daniel Fox has argued that this model of medical regionalization was central to inter-war attempts to modernize and rationalize health services, not just in Britain, but in America also: op. cit., note 18 above.

80 Joint Consultative and Advisory Hospitals Council, General statement of the position of the voluntary hospitals of Sheffield, Sheffield, 1920. The letter, dated March 1919, was reproduced as Appendix A of this document. See also 'Reform of Sheffield Hospitals. Drastic proposals by the Honorary Medical Staffs', Sheffield Daily Telegraph, 11 June 1919.
} 
had been reduced. ${ }^{81}$ By pre-empting government proposals for reforming hospital finances, this scheme was widely perceived as a successful strategy for avoiding state control of the voluntaries. ${ }^{82}$

The Medical School was involved in these developments from the start. It had long proved a neutral setting in which members of staff of the rival voluntary hospitals might pursue a common interest in medical teaching. The war reinforced this spirit of co-operation: when the Army Medical Service established a Territorial General Hospital in Sheffield, the staff was largely drawn from those already associated with the Medical School, who now came to practise as well as teach together. ${ }^{83}$ Hall quickly capitalized on the spirit of camaraderie engendered by this wartime experience when, shortly after the war ended, he was instrumental in setting up a Staff Club for the joint staffs of the two voluntary hospitals. ${ }^{84}$ As rapprochement gave way to more formal collaboration between the hospitals, Medical Faculty members played an important role in the creation of the Joint Hospitals Council. ${ }^{85}$

Moreover, the involvement of the University did not end with securing cooperation between the two hospitals. It was also seen to be crucial to the success of the hospitals' larger plans in a political climate that was increasingly hostile to the voluntary principle. Following the First World War, Labour had gained considerably in influence on the City Council and the Board of Guardians, arousing further fears that local government would come to favour municipalization of the hospital services. ${ }^{86}$ But the support of both these bodies was essential to the co-ordination of

${ }^{81}$ Participants contributed one penny in every pound they earned to the scheme, which was organized through local workplaces. Contributors and their dependents were entitled to "treatment free of maintenance charges at any of the Sheffield hospitals". A Sheffield and District Association of Hospital Contributors was established to administer the scheme. In the first year, 154,000 employees from 1,879 Sheffield firms, and a further 35,000 members from outlying regions, contributed a penny from each pound they earned. With additional voluntary supplements from employers, this provided a revenue of $£ 72,000$. By 1923 this had risen to $£ 102,000$. British Medical Journal, 'Relief for the shortage of hospital beds in Sheffield', Brit. med. J., 1920, ii: 93; idem, 'Co-operation among voluntary hospitals', Brit. med. J., 1923, i: 1027-8; idem, 'Sheffield Joint Hospitals Council', Brit. med. J., 1923, ii: 483; idem, 'Sheffield Joint Hospitals Council', Brit. med. J., 1924, ii: 1176.

82 At the 1923 AGM of the Joint Hospitals Council, for instance, Councillor Mrs Wilkinson urged rejection of government suggestions that voluntary hospitals should accept paying patients, on the grounds that this would open the door to public control, and that the Sheffield scheme made this unnecessary: British Medical Journal, 'Co-operation among voluntary hospitals', op. cit., note 81 above, p. 1027.

${ }^{83}$ On the establishment of the Territorial General Hospitals, which were organized in collaboration with the university medical schools, see W. G. Macpherson, History of the Great War. Medical services: general history, Vol. I, London, HMSO, 1921. The Territorial hospital was accommodated in local schools and in beds made available by the voluntary hospitals. Hall was himself in charge of the medical division: Platt, op. cit., note 47 above, p. 452.

84 Yates, op. cit., note 47 above, pp. 3-4. Hall's chief collaborator in setting up this club was Ernest Finch, another of the new generation of scientifically-oriented clinicians who had worked for a time with Macdonald in the physiology department, and who eventually became professor of surgery and a leading consultant in inter-war Sheffield: Yates, op. cit., note 60 above.

${ }^{85}$ Of the eight doctors who signed the letter from the "Joint Medical Staffs", Hall, Barnes and four others taught clinical subjects in the Medical School: Joint Consultative and Advisory Hospitals Council, op. cit., note 80 above.

86 This was the case in Bradford, for instance, where the Poor Law hospital was municipalized and subsequently rejected the voluntary hospital's proposals for a co-ordinated admissions policy: see Abel-Smith, op. cit., note 78 above, p. 300. On Sheffield politics following the First World War, see Pollard, op. cit., note 24 above, pp. $265 f$. 


\section{Steve Sturdy}

hospital admissions policy and to the successful operation of the contributory scheme ${ }^{87}$ The University, with its long involvement in municipal administration and in technical service work for local industry, was in a position to provide influential support in this respect, and the hospitals quickly turned to it for help: several University representatives were added to the Joint Hospitals Council, including the Vice Chancellor who was appointed chairman, and the Medical Faculty declared their satisfaction at being involved in "deliberation on the many difficult problems which face all voluntary hospitals at present" ${ }^{88}$

This marked a significant shift in the balance of power between the teaching hospitals and the University: for the first time, the hospitals needed the University as much as the University needed the hospitals. Hall and his colleagues on the Medical Faculty were quick to take advantage of this unprecedented situation, by extracting from the clinicians a far more sweeping series of concessions than anything they had envisaged before the war. During 1919, responsibility for the clinical teaching was effectively transferred from the hospital staffs to the Medical Faculty: lay members of the University were for the first time appointed to the Clinical Studies Committee; clinical teachers accepted stringent restrictions on how they should use the time allocated to teaching; and it was agreed that appointments to clinical posts should now be made, not by the Clinical Studies Committee, but by a standing committee of the Medical Faculty. 89

This transfer of responsibility for the bedside teaching was accompanied by a complete reorganization of the clinical curriculum. Previously, students had been assigned to work for a time as clerks or dressers to individual staff members in one or other of the teaching hospitals, where lectures were also given to augment the bedside teaching. But early in 1919, this individualized system of teaching was replaced by a much more organized programme of group tuition. Groups of about ten students now spent six months at one hospital, followed by six months at the other. Each group received instruction in medicine and in surgery on alternate days, so that teaching at the bedside could be co-ordinated with systematic lectures given by the professors of medicine and surgery. ${ }^{90}$ In this way, the University professors were able to assert their intellectual as well as their institutional authority over the ordinary

${ }^{87}$ Both Sheffield Corporation and the Board of Guardians were represented on the committee of the Contributors' Association, as were traditional labour organizations like the Trades and Labour Councils, and more conservative bodies like the Cutlers' Company and the Hospital Sunday Fund: British Medical Journal, 'Sheffield Joint Hospitals Council', op. cit., note 81 above.

${ }^{88}$ Medical Faculty, Annual Report, 1919-1920, copy in SUA 5/1/135. The Vice Chairman and chief administrator of the Joint Hospitals Council for many years was the historian, T. Walter Hall, Arthur Hall's brother; Arthur Hall himself was later prominent in plans to unite the Sheffield hospitals on a single site: Sheffield Hospitals Council, Inc., 'Record of the $1^{\text {d }}$ in the $£$ scheme', Sheffield, 1949.

${ }^{89}$ Medical Faculty, Annual Report, 1919-1920, copy in SUA 5/1/135; report of the sub-committee of the Clinical Studies Committee, inserted in Medical Faculty Minutes, 4 April 1919; Medical Faculty Minutes, 26 June, 2 October 1919. It was agreed that the standing committee would consist of the Professors of Medicine, Surgery, Midwifery, Pathology, Anatomy, Physiology and Public Health.

${ }^{90}$ Report of the sub-committee of the Clinical Studies Committee, inserted in Medical Faculty Minutes, 4 April 1919. This system of teaching actually began operating in March 1919, and was ratified by the formal decision of the Faculty a month later: Medical Faculty, Annual Report 1918-1919, in Medical Faculty Minutes, 27 October 1919. 


\section{The political economy of scientific medicine}

clinical tutors and lecturers, whose work was reduced to illustrating and expanding the principles outlined in the systematic lectures. ${ }^{91}$

The redistribution of pedagogical authority, and the systematic reorganization of the clinical curriculum, also favoured the movement of laboratories and full-time scientists into the hospitals. In 1919, Leathes was appointed Honorary Physiologist on the staffs of the Royal Infirmary and the Royal Hospital. Soon after, the Boards agreed to the appointment of a full-time lecturer and a demonstrator in physiology, who would take charge of new clinical laboratories to be funded half by the University, and half by the hospitals themselves. These laboratories were intended to provide students with "facilities... for working in pathology and physiology in connection with their clinical studies", ${ }^{92}$ and at the same time as the laboratories were established, changes were made in the examination schedule to allow more time for science lectures and laboratory work within the clinical curriculum. ${ }^{93}$ Moreover, the laboratories and scientific staff were also to be available for "important investigations required by the medical staff in dealing with the cases under them", 94 such as would help Hall and his colleagues to consolidate their identity as scientific practitioners.

Finally, this series of scientific reforms was topped off by the creation of a full-time clinical chair of pharmacology. Like the more general restructuring of the clinical curriculum of which it was a part, the creation of this post was facilitated by fears that the government would intervene in the work of the hospitals in ways which would compromise the autonomy of the city's leading clinicians. Even before the war, university reformers in the metropolis had argued that clinical teaching, like the pre-clinical sciences, should be made the responsibility of full-time salaried professors who would be provided with beds in the teaching hospitals. These views had been adopted by the Board of Education, and from the end of the war by the newly-established University Grants Committee (UGC). By 1919, steps were being taken to establish full-time clinical chairs of medicine and surgery in a number of the

91 "The systematic lectures in medicine and surgery will thus regain much of their former prestige which they have lost to a great extent owing to their being divorced from the patient". Report of the sub-committee of the Clinical Studies Committee, inserted in Medical Faculty Minutes, 4 April 1919.

92 Medical Faculty, Annual Report, 1920-1921, copy in SUA 5/1/26, f. 354.

${ }^{93}$ By shortening the pre-clinical physiology course and setting the 2nd MB examination six months earlier than in other universities, space was made to incorporate new lectures and laboratory courses in applied physiology and anatomy into the clinical work. On the negotiations over these changes, see report of the sub-committee of the Clinical Studies Committee, inserted in Medical Faculty Minutes, 4 April 1919; and Clinical (Medical) Studies Committee, 'Report re Chair of Pharmacology and proposed modification in curriculum', inserted in Medical Faculty Minutes, 2 October 1919. This was a unique experiment in restructuring the British clinical curriculum; though much cited in the inter-war literature on medical education reform, the scheme was not adopted anywhere else, and was abandoned in Sheffield in 1947. It seems to have been an extension of reforms pioneered at the University of Toronto, where the chair of pathological chemistry to which Leathes was recruited was "created for the very purpose of giving a scientific term to the final professional subjects": A. B. Macallum to William Osler, 14 April 1908, University of Toronto, Thomas Fisher Rare Books Library, A. B. Macallum papers, B66-0005/001(01).

94 Medical Faculty, Annual Report 1919-1920, copy in SUA 5/1/35. An important precedent had been set by Leathes, who was given charge of the nephritis wards at the Territorial General Hospital during the war, and there established clinical laboratories to conduct his own research. See J. B. Leathes, 'Renal efficiency tests in nephritis and the reaction of the urine', Brit. med. J., 1919, ii: 165-7. The lecturer appointed to take charge of the new hospital laboratories was C. G. Imrie, a chemical physiologist who had previously worked with Leathes in Toronto. 


\section{Steve Sturdy}

London hospitals, and it seemed likely that similar chairs would be imposed on teaching hospitals throughout the country. ${ }^{95}$

Such plans were deeply threatening to the professional interests of hospital doctors. Hitherto, clinical teaching had provided a way for them to advertise their professional standing, to the benefit of their private practices. If teaching posts were now to be divorced from private practice, such advantages would be lost. Moreover, titles and posts that had previously been the mark of an élite private practitioner would now come to be identified with full-time salaried work. Clinical teaching would tend to become the domain, not of clinicians, but of professional full-time academics, and so would the wards on which those academics taught and practised. At the time, clinicians were worried, not only that the state would take control of the voluntary hospitals, but that it would also replace honorary appointments with salaried posts, as a step towards creating an entirely salaried medical profession in Britain. ${ }^{96}$ Full-time clinical chairs thus appeared as the thin end of a wedge that would eventually separate hospital work from private practice.

In this climate of concern, Hall and his colleagues were able to present their plan for a chair of pharmacology as a more acceptable alternative to the imposition of a full-time chair of clinical medicine. This plan was presented to the hospitals in October 1919, in a report drawn up by a sub-committee of the Clinical Studies Committee. Pointing out that it was "well known" that the Board of Education planned to turn existing part-time clinical chairs into full-time posts, the subcommittee recommended instead

That a Department of Pharmacology be staffed and equipped with laboratories, and that it should be recognized that the teaching of this subject should be in part in the laboratory, but in part also, in the wards, where the Professor of Pharmacology should have beds, and illustrate his teaching by the results obtained in the treatment of selected patients with the appropriate pharmacological agents. ${ }^{97}$

Such an arrangement would greatly advance Hall's programme of integrating full-time scientists more closely into both the educational and therapeutic work of the

\footnotetext{
95 The prime mover behind this scheme was George Newman, Chief Medical Officer to the Board of Education from 1917, and CMO to the Ministry of Health and medical assessor to the University Grants Committee from 1919. It was Newman's view, in 1918, that "At the end of five years it is quite possible that we might have half-a-dozen Schools in London and half-a-dozen in the country with a complete [full-time] unit system": Newman, 'Grants to medical schools', memorandum to the Secretary of the Board of Education, 22 October 1918, PRO ED 24/1961. On the establishment of the London chairs, see George Graham, 'The formation of the medical and surgical professorial units in the London teaching hospitals', Annals of Science, 1970, 26: 1-22.

96 The Dawson Report had already suggested that pro-rata payments might be introduced for clinicians working under a reorganized hospital system, and it was widely suspected that this was intended as a first step towards a fully salaried and completely unified system of state hospitals. On the educational side, Newman clearly saw a connection between the reorganization of medical education and that of the health care system, including the hospitals. See: George Newman, Some notes on medical education in England. A memorandum addressed to the President of the Board of Education, Cd. 9124, London, HMSO, 1918; and idem, An outline of the practice of preventive medicine. A memorandum addressed to the Minister of Health, Cmd. 363, London, HMSO, 1919.

${ }^{97}$ Clinical (Medical) Studies Committee, 'Report re Chair of Pharmacology and proposed modification in curriculum', inserted in Medical Faculty Minutes, 2 October 1919.
} 


\section{The political economy of scientific medicine}

hospitals. "Experimental Pharmacology", said the report, "of all the branches of science is the one that comes nearest to the practice of Medicine", and the creation of a clinical chair in pharmacology would thus "do much to impress in a medical school the interdependence of experimental investigation and clinical practice". ${ }^{98}$ But it would do so in such a way as to complement rather than undermine the status of the existing part-time professors of medicine and surgery.

These arguments proved compelling. By December the Royal Infirmary had given "some assurance" that it would be prepared to appoint a suitable pharmacologist to a full physicianship, and the University recorded that the chair should be created "subject to the Government's providing two-thirds of the salary of the Professor". 99 Meanwhile, the Board of Education and the UGC were being urged to accept a chair of pharmacology as a reasonable alternative to a chair of medicine, on the grounds "(a) that it would better suit the particular needs of Sheffield, (b) that it would cost considerably less." ${ }^{100}$ By February 1920, the UGC had agreed that the creation of a clinical chair would provide "the means of teaching Pharmacology not merely as an abstract science but in its clinical applications", and that this arrangement was "likely to make for an advance in Medical Education in the University". ${ }^{101}$

Whatever doubts the UGC may have had about the Sheffield arrangements seem finally to have been allayed by the fact that "the right man for the post was available". ${ }^{102}$ Edward Mellanby was already well known in official as well as medical circles for his work on the causation of rickets. ${ }^{103}$ Moreover, he was greatly attracted by the possibility of conducting clinical research-so much so, in fact, that he was prepared to turn down offers from more prestigious institutions if the Sheffield chair

\footnotetext{
${ }^{98}$ Ibid.

${ }^{99}$ Medical Faculty Minutes, 1 December 1919; Finance Committee Minutes, December 1919. As usual, back-stage negotiations smoothed the way to this agreement. A. E. Barnes, by this time a full physician at the Royal Infirmary, was a key figure in these moves. Though appointed to the part-time lectureship in materia medica in 1914, he regarded it as a "weary and utterly useless residue from the old curriculum", and told the Faculty "that pharmacology was a subject requiring a whole timer with special training and that I should resign as soon as such could be obtained": Barnes, 'Medical student days', op. cit., note 21 above, f. 9. The Faculty began considering a "new and important Department of Pharmacology" sometime in 1917-18, but discussion was deferred until Barnes returned from war service. With the systematization of the clinical curriculum, two new lectureships in clinical medicine were created to undertake the extra load of formal teaching, to one of which Barnes was appointed in June 1919, leaving vacant the part-time lectureship in materia medica. Meanwhile W. S. Porter, a colleague of Barnes at the Royal Infirmary, agreed to resign his physicianship if "a more congenial colleague" could be found. Medical Faculty Minutes, 1 October and 25 November 1918, and 4 April, 2 June and 26 June 1919; Barnes, 'Medical student days', op. cit., note 21 above, f. 20.

${ }^{100}$ Henry Hadow (Vice Chancellor of Sheffield University) to William McCormick (Chairman of the UGC), 31 January 1920, SUA 5/1/135. Hadow seems to have been confused by Hall and Leathes's manoeuvring, and told McCormick: "I have been working under a misunderstanding which was not altogether, I think, my fault. The proposal for starting a Clinical Unit came up before my appointment. On my arrival I was told that it was in prospect and that if we could [see] to it the Board [of Education] would provide three quarters of the running expenses. I naturally understood this to mean that there was some separate scheme of medical education to which we could look for our proportion of the funds ... We talked this over all last term and came up to see Sir George Newman on Wednesday last to see whether he approved of the subject of the proposal. He entirely approved, but explained that there was no special fund and that the only source of income was your Committee."

${ }^{101}$ UGC minute, 11 February 1920 , PRO UGC $1 / 1$. This was the only such grant awarded outside London.

102 Hadow to McCormick, 31 January 1920, SUA 5/1/135.

${ }^{103}$ Henry H. Dale, 'Edward Mellanby 1884-1955', Biogr. Mem. Fellows Roy. Soc., 1955, 1: 193-222.
} 


\section{Steve Sturdy}

became available. ${ }^{104}$ Mellanby's candidature satisfied all parties: the Royal Infirmary made an honorary staff post available, the UGC provided the necessary financial support, and Mellanby was duly appointed to the chair. His arrival marked the start of a period of rapid growth in clinical research and teaching at Sheffield; his reputation enabled him to attract new funds, facilities and staff, ${ }^{105}$ and by the time he left he had made his chair into what the proponents of clinical science regarded as "very much one of the bright spots in recent years in British medicine". 106

\section{SCIENCE AND THE REMAKING OF MEDICAL CULTURE}

The creation of the pharmacology chair marked the maturation of Hall's campaign to establish a new kind of scientific medicine in Sheffield. By giving a full-time University professor control of his own patients, the hospitals finally agreed that professional scientists should be allowed to play a responsible role in the work of healing. This was an important point to win in the context of the University's struggle to gain control of hospital medicine. But it also had important implications for the reorganization of medical practice beyond the walls of these institutions.

This became clear when, less than a year after his appointment, Mellanby announced that his research in Sheffield had led him to a cure for exophthalmic goitre, which was relatively common in the Sheffield region. ${ }^{107}$ It was an impressive demonstration of Mellanby's powers of investigation, and proved to be an effective advertisement for the changes taking place in the Medical School. Following Mellanby's announcement, the local National Health Insurance (NHI) Panel Practitioners' Committee donated $£ 1,000$ to Mellanby's laboratory "to promote the policy of bringing physiology into closer relation with the practise and teaching of

\footnotetext{
104 Mellanby was presumably familiar with developments in Sheffield from as early as 1916, when he became external examiner in pharmacology to the University. He turned down the chair of physiology at Manchester in favour of the Sheffield post (Edward Mellanby to A. V. Hill, 4 April 1920, in A. V. Hill papers, Churchill Archive Centre, AVHL II/4/61). It seems that he also refused a number of later offers, including a very attractive one from Edinburgh (Dale, op. cit., note 103 above, p. 204), and he remained in Sheffield until 1933, when he was appointed Secretary of the Medical Research Council. Though Mellanby's earlier work on rickets was conducted with dogs, he had also carried out clinical investigations of other conditions. See Edward Mellanby, 'A short chemical study of a case of cyclical vomiting, with some remarks on creatinuria and acidosis', Lancet, 1911, ii: 8-12; idem, 'An experimental investigation on diarrhoea and vomiting in children', $Q . J$. Med., 1915-16, 9: 165-215.

${ }^{105}$ Besides the UGC grant towards his appointment, Mellanby's work in Sheffield was supported by the Medical Research Council, which had funded much of his previous research. Other research workers paid for by the MRC included May Mellanby, Edward's wife and a formidable scientific figure in her own right, and Edward Mellanby's assistant, S. J. Cowell, a "biochemically oriented physician" who dealt with most of Mellanby's clinical duties while the professor worked on his dogs (obituary, Stuart Jasper Cowell, in Gordon Wolstenholme (ed.), Munk's roll, vol. 6, Oxford, IRL Press, 1982, pp. 124-6, on p. 125). Subsequently, in 1926, $£ 10,000$ in research funding was awarded by the Yorkshire Council of the British Empire Cancer Campaign, which provided "the opportunity of extending Professor Mellanby's Department by the addition of a new laboratory": Medical Faculty, Annual Report, 1925-1926, copy in SUA $5 / 1 / 64$, f. 7 .

106 Thomas Lewis to Arthur Hall, 5 July 1933, SUA 5/1/128, f. 23.

107 Primed by his work on specific dietary deficiencies, and by other physiological studies in this area, Mellanby and his wife quickly showed that the goitre could be treated with iodine, cod liver oil and other dietary adjustments: Edward Mellanby and May Mellanby, 'The application of the results obtained in experiments on the hyperplasia of dogs' thyroids to the treatment of exophthalmic goitre (Graves' disease)', J. Physiol., 1921, 55: xP; S. J. Cowell and E. Mellanby, 'The effect of iodine on hyperthyroidism in man', $Q . J$. Med., 1924-25, 18: 1-26.
} 


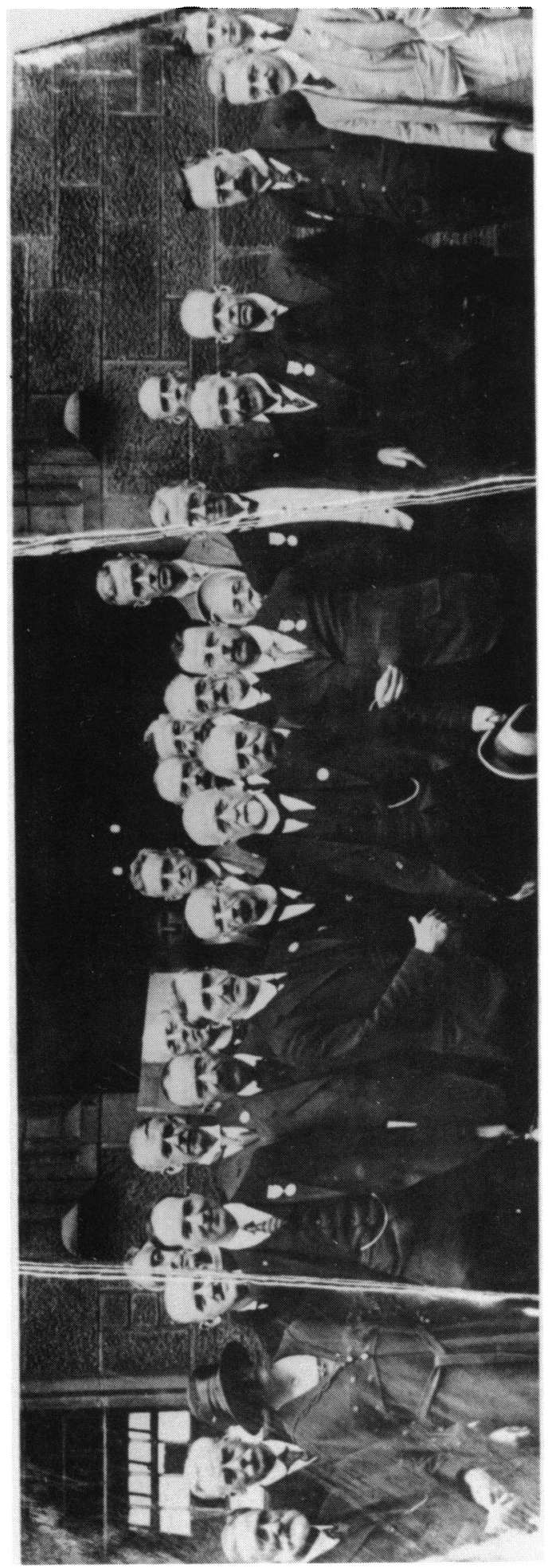

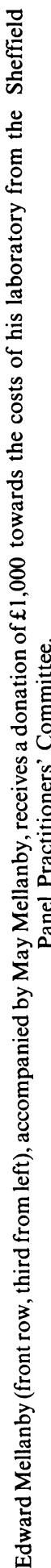


clinical medicine". ${ }^{108}$ Arthur Hall was particularly gratified by this response, and promptly wrote to the British Medical Journal, pointing out what he saw to be some of the implications of the Panel Practitioners' gesture. It was not just that "the clinician and the laboratory worker have found ... a mutual advantage in coming more closely together". More that this, said Hall, "there have been, latterly, many signs, in this area at any rate, that the gulf which has for so long separated members of hospital staffs from general practitioners may soon be bridged over. The generous gift of the Medical Panel Committee of Sheffield has laid a solid foundation for one pier of the Bridge, and with this excellent start I have no doubt whatever that the structure will soon be complete." 109

This rapprochement between general practitioners (GPs) and hospital doctors represented a further step towards the fulfilment of Hall's campaign to establish a new division of medical labour in Sheffield. The growth of private consulting practice, for instance, depended on a reorientation of the social relations of the medical profession: instead of building up their practices by cultivating the goodwill of individual patients, leading doctors now relied to a greater extent on referrals from GPs. Likewise, the reorganization of the work of the voluntary hospitals involved a new degree of professional cohesion, and the exclusion of lay influence from medical decision-making. Thus, before the penny-in-the-pound scheme was set up, admission to either a Poor Law or a voluntary hospital depended, respectively, upon a means test or a recommendation by a hospital donor: admission was primarily a matter of lay philanthropy, controlled by wealthy patrons and Poor Law Guardians. Under the penny-in-the-pound scheme, however, admissions to both kinds of hospitals came to depend primarily on referrals by doctors. ${ }^{110}$ Even more than in private practice, this implied a network of intra-professional relationships which cut across class boundaries to link the élite staffs of the voluntary hospitals with Poor Law medical officers, National Insurance panel doctors, and other more lowly GPs. ${ }^{111}$ Indeed, as collaboration between Poor Law infirmaries and voluntary hospitals and between state-supported NHI doctors and private consultants became increasingly common, this network even blurred the boundary between public and private practice, and

\footnotetext{
${ }^{108}$ British Medical Journal, 'Physiology and clinical medicine in Sheffield', Brit. med. J., 1921, i: 648. The Panel practitioners had accumulated this money as a wartime contingency fund, saved from their Panel

${ }^{109}$ Arthur J. Hall, 'Physiology and clinical medicine in Sheffield', Brit. med. J., 1921, i: 688.

110 Initially, in 1920, the Ecclesall Guardians agreed to suspend means tests on patients referred by general practitioners directly to the workhouse infirmary, provided those patients could pay $24 \mathrm{~s} .6 \mathrm{~d}$. per week towards the cost of accommodation. Under the penny-in-the-pound scheme, this referral system was extended to include all the Sheffield hospitals, though it was stressed that "Contribution confers no guarantee of treatment at a voluntary hospital". 'Relief for the shortage of hospital beds in Sheffield', and 'Sheffield Joint Hospitals Council' (1923), op. cit., note 81 above.

${ }^{11}$ The Contributors' Association tacitly acknowledged the importance of referrals when they set up an ambulance service to convey patients from home to hospital, and from GP to consultant. 'Sheffield Joint Hospitals Council' (1923), op. cit., note 81 above. The emergence of complex and extensive social and technical networks for managing various public utilities at this time has recently been the subject of a number of highly stimulating historical studies. See: Joel A. Tarr, 'The city and the telegraph: urban telecommunications in the pre-telephone era', J. Urban Hist., 1987, 14: 38-80; Joel A. Tarr and Gabriel Dupuy, Technology and the rise of the networked city in Europe and America, Philadelphia, Temple University Press, 1988.
} fees. 
obscured the divergent political and professional interests that this divide had previously sustained. ${ }^{112}$ As Hall had long hoped, the various sectors of the local medical profession were beginning to co-operate in providing a system of health care which would cover the entire population of the city and its region. ${ }^{113}$

Clearly, the development of laboratory science was deeply implicated in what was, in effect, a transformation in the professional politics of medicine in Sheffield. What has not yet been made clear, however, is quite what role science played in that transformation. Certainly, we should not suppose that this kind of political change can simply be attributed to the growth of scientific knowledge or technique. On the contrary, I have argued that, in the sphere of hospital medicine at least, the introduction of laboratory methods into practice was dependent upon, rather than responsible for, a shift in institutional politics. By the same token, if we are to explain the reorganization of medical practice in Sheffield as a whole, I would argue that it is not enough simply to point to the impact of innovations like Mellanby's treatment for goitre. Rather, we must describe the political and social circumstances which not only made medical reorganization seem desirable, but also gave scientists a peculiar authority in such matters. And in order to do that, it is necessary to look more closely at the development of civic culture generally in Sheffield at that time.

In the period between 1890 and 1925, administrative and managerial interests came to play a dominant role in many aspects of public life in Sheffield. As in other industrial cities, this was prompted primarily by the demands of an increasingly organized and vociferous working class. In response, various steps were taken to minimize class conflict by palliating the worst injustices of working-class life, and by regulating such areas of public and private life as were considered to pose a particular threat to the prevailing social order. Bolstered by the cognate development of new professional managerial structures in industry, this led, in Sheffield as elsewhere, to an expansion of local government machinery, the development of new forms of professional organization, and a shift in the political orientation of bodies like the city Council and the Board of Guardians away from Tory paternalism towards more

\footnotetext{
$112 \mathrm{NHI}$ seems to have been particularly important in laying the foundation of this kind of collaboration. Indeed, with the state subsidizing the capitation fees paid to private doctors, the NHI system itself helped to blur the boundary between the public and private sectors. Moreover, Anne Digby and Nick Bosanquet have suggested that the principle of per capita payments for NHI practice encouraged panel doctors to refer difficult, and hence uneconomic, cases to consultants: Digby and Bosanquet, 'Doctors and patients in an era of national health insurance and private practice', Economic History Review, 2nd series, 1988, 41: 74-94.

${ }^{113}$ Collaboration between the public and private sectors was necessary, for instance, for the effective operation of the infectious diseases notification schemes set up around 1900, and Hall recalled that Robertson, "by his tact and charm of manner ... won the esteem and goodwill of the general practitioners. Indeed, he did more than any M.O.H. before him to bring practitioners to trust the Health officials and to realise that the ultimate object of both was identical; a happy state of affairs that did not always exist here." Hall, op. cit., note 21 above, p. 53.

Cf. Patrice Pinell, "Cancer policy and the health system in France: "big medicine" challenges the conception and organization of medical practice', Soc. Hist. Med., 1991, 4: 75-101, which argues that the emergence of "big medicine" in France in the inter-war years involved an unprecedented degree of collaboration between the public and private sectors for the efficient use of capital-intensive resources. For the situation in America, cf. Starr, op. cit., note 10 above, passim.
} 
Liberal and even Radical views, especially on welfare policy. ${ }^{114}$ Indeed, the question of health and welfare was one of the main foci around which this new administrative and managerial culture began to take shape, with the Sheffield health authority, in particular, taking the lead in promoting new ways of regulating and organizing the life of the city. ${ }^{115}$

Similar interests informed the work of Arthur Hall and his colleagues in the Sheffield Medical School, who chose to link their own careers to the growth of this new administrative culture. Thus they rejected the predominantly Tory politics of the older members of the local medical élite in favour of more Liberal programmes of medical reform, including the establishment of National Health Insurance to remedy some of the deficiencies of health care for the working class. ${ }^{116}$ And as we have seen, they did much to promote the development of the University as a centre of the new civic culture, especially by tailoring the scientific work of the Medical School to the concerns of public health and industrial management. Thus the distinctly serviceoriented programme of laboratory science that they built up can be seen as a way of integrating themselves more closely into the work of civic administration.

This is particularly clear in the case of the public health work conducted in the Medical School. Even before the development of bacteriology, the growth of the public health movement in nineteenth-century Britain had provided the impetus for a variety of scientific innovations, including social statistics, sanitary science, and both contagionist and anti-contagionist theories of epidemic disease, all of which yielded new techniques for surveying society and its environment so as to identify appropriate sites for administrative intervention. ${ }^{17}$ Laboratory-based techniques like bacteriology and chemical physiology marked a further stage in the refinement of this technology of surveillance and control. They thus contributed to the development of new administrative responses to the social and political problems of the industrial city, and they did so, moreover, in ways which helped to minimize both the financial

\footnotetext{
${ }^{114}$ Smith, op. cit., note 24 above, pp. 241-7; Pollard, op. cit., note 24 above, pp. 265-8. On the formation of managerial and professional politics more generally, see also Harold Perkin, The rise of professional society: England since 1880, London, Routledge, 1989.

115 The establishment of the tuberculosis notification schemes can be seen in this light. Prior to this, the local public health authority had actively agitated for sanitary reform, and, following the Housing Act of 1890 , succeeded in pushing through a programme of slum clearance against opposition from the Council: Pollard, op. cit., note 24 above, pp. 93-105. See also Derek Frazer, Power and authority in the Victorian city, Oxford, Basil Blackwell, 1979, pp. 139-48.

${ }_{16}$ Christopher Addison, one of the key figures in the establishment of the NHI system, had served from 1897 to 1901 as the first full-time teacher of anatomy at the Sheffield Medical School. While there, he apparently "kept his politics to himself. It would have been very advisable in such a conservative centre as Sheffield then was." One aspiring young surgeon was evidently "driven out [because] he was not Tory enough!" A. E. Barnes, 'Medical student days', op. cit., note 21 above, f. 11. Among the younger clinicians, Barnes, at least, was a keen advocate of NHI: obituary, in Gordon Wolstenholme (ed.), Munk's roll, volume 5, Oxford, IRL Press, 1965, pp. 28-9. For a more nuanced analysis of the politics of the medical élite in Sheffield in the mid-nineteenth century, see Smith, op. cit., note 24 above, pp. 151-4, 159.

${ }_{117}$ An important statement of this point is Roger Cooter, 'Anticontagionism and history's medical record', in P. Wright and A. Treacher (eds), The problem of medical knowledge, Edinburgh University Press, 1982, pp. 87-108. On statistics see John M. Eyler, 'Mortality statistics and Victorian health policy: program and criticism', Bull. Hist. Med., 1976, 50: 335-55; Karl H. Metz, 'Social thought and social statistics in the early nineteenth century: the case of sanitary statistics in England', Int. Rev. Soc. Hist., 1984, 29: 254-73.
} 
cost and the social disruption that such intervention entailed. ${ }^{118}$ By adopting an entrepreneurial role in developing and supplying such technical resources, Hall and his colleagues were able not only to finance the expansion of the Medical School's scientific facilities, but also to establish themselves as influential and respected figures among the city's emerging administrative élite.

This political influence was to prove crucial in enabling Hall and his University colleagues to take their programme of medical science into the voluntary hospitals. For while anonymous laboratory-based techniques of diagnosis might be appropriate for managing the health of a predominantly working-class population, they were of less interest, and indeed might be seen as threatening, to those clinicians who continued to build their practices primarily around the personal relationships they established with their patients. As a result, such techniques were incorporated into hospital medicine relatively slowly, and did little to win the University teachers any significant influence in the work of hospitals. Nor did this situation change until after the First World War, when the hospitals came under outside pressure for reform, and were compelled to seek assistance from other civic institutions, among which the University now enjoyed a dominant position. For the first time, University scientists were able to demand a responsible role in the investigation and treatment of patients, and especially in the clinical training of future generations of doctors. And once in control of the clinical teaching, the Medical Faculty was able to institute a series of reforms which brought the laboratory into far closer contact with hospital practice.

Like the developments in public health science that preceeded it, this expansion of the scientific work of the Medical School was informed by the interests of the administrative culture that made it possible. But, unlike the growth of public health administration, which developed parallel with, but largely independent of, curative medicine, the reform of hospital teaching involved the imposition of new administrative values on an existing medical culture. As such, it illustrates particularly clearly another aspect of the role played by science in the pursuit of administrative interests: where my discussion of the public health laboratory has focused on how science was used to conceptualize society and its environment, analysis of the scientific reform of the clinical curriculum enables us to see how science was also used to organize the administrative machinery itself, in this case as represented by the medical profession.

\footnotetext{
118 The Secretary of the MRC, Walter Fletcher, spelled this out in the address he delivered at the opening of Mellanby's laboratory in Sheffield. Fletcher recalled a government Minister who once "cheerfully and frankly said to me, 'Well, doctor ... If we want to stop disease we must give the people better grub and less dirt". "I entirely agreed", Fletcher told his audience, provided the Minister "could tell me what better grub was and what less dirt was, for I know no way of finding out those two things except by persistent scientific research work". To illustrate this point, Fletcher argued that recent research had shown that "a great deal of the modern plumbing which is insisted upon by various by-laws is really unnecessary," to the extent that "the cost of housing might be cut down in an important way if science were allowed full play ... in the devices which are now used." In relation to "better grub", Mellanby's work on vitamins, and now on goitre, promised a similar saving in the cost of welfare measures. Walter Fletcher, 'Medical research and daily life', Brit. med. J., 1922, ii: 941-3. On the politics of nutrition science, including Mellanby's work, at this time, see: David Smith and Malcolm Nicolson, 'The "Glasgow School" of Paton, Findlay and Cathcart: conservative thought in chemical physiology, nutrition and public health', Soc. Stud. Sci., 1989, 19: 195-238; Naomi Aronson, 'Nutrition as a social problem: a case study of entrepreneurial strategy in science', Soc. Probl., 1982, 29: 474-87.
} 
The key to this was the way in which the clinical teaching was restructured, both socially and intellectually. Previously, students had been expected to build up a working knowledge of medicine by following the day-to-day practice of their individual tutors: their clinical experience thus depended on the contingencies of hospital admissions and on the individual peculiarities of the cases treated by their tutors. But with the transfer of pedagogical authority from the hospital tutors to the professors of surgery and medicine, it became possible to impose a new intellectual order on the bedside teaching. Priority was now given to the systematic lectures in medicine and surgery, which the tutors were required to illustrate with reference to appropriately selected patients, while such cases as did not readily fit this schema were ignored. The individual patient thus ceased to be the starting point from which medical knowledge was to be elaborated, and instead became merely a particular instance of some more general category of knowledge as conceived by the clinical professors.

This had important implications for how students were expected to conduct their own medical practices after completing their training. The old system of individual tuition had supposed that, like their hospital tutors, they should be able to make sense of and treat whatever cases were admitted to their care, no matter how difficult or idiosyncratic. Under the new system, on the other hand, they were trained to deal only with such cases as could be understood in terms of the system of knowledge outlined by the clinical professors. As for those cases which could not be categorized in this way, the implication was clear: they should be referred to someone with a greater command of the necessary knowledge and experience. The new clinical curriculum was thus intended primarily as a way of redefining the sphere of general practice, by providing what was considered to be an appropriate body of medical knowledge for a GP, and by encouraging the referral of difficult cases to more highly qualified hospital doctors and University clinicians. ${ }^{119}$ In effect, the new intellectual organization of the clinical teaching not only reflected the hierarchy of authority that now existed within the Medical School, but also provided a means of extending that hierarchy out into the world of medical practice, in the form of a new division of labour between GPs and consultants. ${ }^{120}$

\footnotetext{
119 The training of the general practitioner became an increasingly dominant theme in campaigns for the reform of medical education in Britain from the mid nineteenth century onwards, and reached a crescendo in the years following the First World War in the context of efforts to reorganize the whole British system of health care: Charles Newman, The evolution of medical education in the nineteenth century, London, Oxford University Press, 1957, pp. 194-264; George Newman, op. cit., note 96 above; idem, Recent advances in medical education in England. A memorandum addressed to the Minister of Health, London, HMSO, 1923. Though general practice does not appear to have been explicitly discussed in relation to the Sheffield reforms, Leathes subsequently became a dominant figure on the education committee of the General Medical Council, where he advocated similar curricular reforms as a way of reorganizing general practice: see Medical Faculty Minutes, 29 October 1934, 1 October 1935. And for a highly programmatic discussion of the ideology of general practice at this time, see David Armstrong, Political anatomy of the body: medical knowledge in Britain in the twentieth century, Cambridge University Press, 1983, pp. $73-84$.

120 The University teachers also sought to extend their intellectual authority further into the local medical community by establishing, in the academic year 1911-12, regular postgraduate refresher courses for GPs in the region: Medical Faculty, draft Annual Report, included in Medical Faculty Minutes, 26 September 1912. For other examples of the growing interest in postgraduate training at this time, see Charles Newman, 'The rise of specialism and postgraduate education', in F. N. L. Poynter (ed.), The evolution of medical education in Britain, London, Pitman, 1966, pp. 169-93.
} 
The programme of laboratory science that Hall and his full-time colleagues had built up in the pre-clinical departments played an important role in legitimizing and reinforcing this new social and intellectual hierarchy. Clinical pathology and chemical physiology, in particular, provided a theoretical framework around which clinical knowledge could be reorganized, while the introduction of laboratory work into the bedside teaching provided the means of making manifest the underlying principles that individual cases were supposed to exemplify. Seen in this light, the connections between Hall's campaign to build up the laboratory sciences in the Medical School and his desire to establish a system of consulting practice in the city become much clearer. For, so long as the local medical profession remained little more than an association of largely independent practitioners, a knowledge of anatomical topography and experience of dissection provided a sufficient basis for the individual skills of diagnosis and surgical manipulation on which a successful practice was seen to depend. In contrast, Hall's efforts to shift the focus of medical training from anatomy to the laboratory sciences offered a way both of restructuring medical knowledge around the elaboration of general scientific principles, and of establishing a more hierarchical system of medical practice. ${ }^{121}$

Once this organizational aspect of Hall's programme of scientific medicine is recognized, there is no need to invoke the impact of new medical knowledge or techniques to explain the eventual adoption of laboratory science by the Sheffield medical profession. While therapeutic innovations like Mellanby's method of treating goitre undoubtedly helped to vindicate scientific research, they were incidental to the main purpose of scientific reform, which was to foster a new division of medical labour by redistributing such knowledge as already existed. And by the end of the First World War, there were strong political reasons for adopting this new division of labour. This political dimension is clearest in the reform of the voluntary hospitals, which played so important a role in the organization and identity of the local profession. Previously, the institutional politics of the hospitals had been dominated by the interests of those wealthy individuals who saw them as a means of dispensing patronage to patients and practitioners alike. But as public health became a major theme in urban politics towards the end of the century, particularly as a focus for new forms of civic administration, so pressure began to grow for the hospitals to adopt the same administrative values and to address themselves more efficiently to the problems

\footnotetext{
${ }^{121}$ It should be noted, however, that anatomy is not inherently individualized, nor are the laboratory sciences inherently systematic in this sense: in either case, individual skills or fundamental unifying principles can be emphasized. Indeed, the situation was reversed in Edinburgh in the 1880s, where scientific reformers favoured the dissecting rooms over the physiology laboratory because anatomy was taught in a more systematic manner: see Steve Sturdy, 'Naturalism and the reform of medical education in late nineteenth-century Edinburgh', paper given to the American Association for the History of Medicine, Cleveland, Ohio, 3 May 1991. Similar issues seem to have been involved in negotiations over the reform of the anatomy teaching in Sheffield, particularly in 1904, when the professor of anatomy, C. J. Patten, sought to add embryology, morphology and physical anthropology to the "limited branch ... of Topographical and Applied Anatomy" that had previously been taught to medical students: Patten to University Senate, April 1904, and other correspondence, SUA 5/1/26, ff. 53-83. A complementary analysis of the social relations of the medical teaching laboratory is to be found in Larry Owens, 'Pure and sound government: laboratories, playing fields, and gymnasia in the nineteenth-century search for order', Isis, 1985, 76: 182-94.
} 
of maintaining the health of a large industrial population. ${ }^{122}$ When the creation of the Ministry of Health and the publication of the Dawson Report raised the threat of government intervention, the Sheffield hospitals were forced to accept the need for reform. And in turning to the University for assistance, they finally accepted the new civic administrative culture in which Hall and his scientific colleagues were so deeply involved.

At the same time, the hospitals also accepted the programme of medical science that Hall and his colleagues had built up, and that now came to be associated, not just with public health administration, but also with the reform of hospital admissions and the growth of consulting practice. Indeed, Hall and his colleagues emphasized the practical and especially administrative benefits that they believed would follow from the reorganization of the clinical teaching along more systematic and scientific lines. The reorganization of the clinical curriculum, for instance, would permit "a much more economical arrangement of the teaching" than had previously been the case. ${ }^{123}$ But these gains would multiply as the new curriculum led to greater collaboration between GPs and consultants of the sort that was already being identified with the development of medical science in Sheffield: "When such a thing once comes about," Hall told the readers of the British Medical Journal, "it will require but little more to acquire all that is of real importance in the Dawson Committee's findings, and practically at very little cost." 124 In other words, the growth of scientific medicine in Sheffield offered a way of fulfilling the demands of both local and national government for administrative reform of medical practice, while at the same time retaining the independence of the voluntary hospitals and their staffs from overt state control.

It is in such terms, then, that we need to explain the rise of scientific medicine in Sheffield. It was primarily a social and political phenomenon, deeply embedded in the development of a new administrative and managerial culture in the city. Like that wider culture, scientific medicine was a response to the problems of maintaining order in a large industrial population, in this case by managing the health of that population. And as such, it was the product of a political process of accommodation and compromise between older philanthropic and newer managerial institutions and practices, and between the public and the private spheres. Moreover, the general constitution of that compromise was such that scientific medicine in Sheffield was, on the whole, a conservative development: in spite of the opposition of some older clinicians, it represented the assimilation of an earlier medical élite to a new position of responsibility in a society still structured by the same class divisions. And while the administrative middle class was to an extent enlarged and consolidated by the new internal cohesion of the medical profession, by the exclusion of lay opinion from medical judgments, and by the growth of collaboration between public and private

\footnotetext{
122 See the work on hospital management cited in note 14 above. And on primary care in relation to hospitals, see Irvine S. L. Loudon and Rosemary Stevens, 'Primary care and the hospitals', in John Fry (ed.), Primary care, London, Heinemann, 1980, pp. 139-75.

${ }^{123}$ Report of the sub-committee of the Clinical Studies Committee, inserted in Medical Faculty Minutes, 4 April 1919, SUA 8/5/6.

${ }^{124}$ Hall, op. cit., note 109 above.
} 


\section{Steve Sturdy}

health services, divisions of class were nevertheless maintained in the strictly hierarchical distribution of power and influence within the profession.

The development of medical science played a key role in establishing this hierarchy, in particular by creating different social identities for those who produced medical knowledge and those who merely applied it in practice: in the sphere of conventional medical practice as much as public health medicine, the development of a hierarchically structured body of scientific knowledge and routine technique should be seen as, in effect, a cognitive technology for organizing both the world of health and illness and the administrative and professional machinery that was used to regulate that world. And within this new cognitive framework, the University professors who now had control of the definition and distribution of medical knowledge were thus able to secure for themselves the role of medical managers within a small and highly select administrative élite.

Whether these conclusions can be generalized to other contexts remains to be seen. Certainly, the Sheffield story is in many respects an idiosyncratic one. The city's peculiar class structure meant that, compared with its neighbours, the University was relatively short of funds, and so was under peculiarly intense pressure to involve itself in the development of a civic administrative culture. Moreover, the relative ease with which a successful programme of medical and especially clinical science was established in Sheffield owed much to Arthur Hall's remarkable skill in mediating between divergent philanthropic and administrative interests within the medical profession and more generally. In particular, Hall's success was in large part due to the facility with which he manipulated the boundaries that separated pure from applied science, science from medical practice, and private from public medicine, in such a way as to undermine the conflicting interests that these boundaries sustained. The fact that this depended so clearly upon the peculiarities of local politics and personalities suggests that scientific medicine could have taken quite different forms under other circumstances.

Nevertheless, there are indications that some of the same social and political interests as lay behind the development of medical science in Sheffield may also have informed similar developments elsewhere. Thus a number of other provincial universities pursued similarly entrepreneurial strategies to build up their laboratory facilities, and likewise seem to have favoured the kind of co-ordinated programme in bacteriology, chemical pathology and chemical physiology that would win them access both to public health administration and hospital practice. ${ }^{125}$ Equally, in at least one other provincial medical school, a similar struggle was enacted between surgeons and anatomists on the one hand, and laboratory scientists and reforming physicians on the other. ${ }^{126}$ Moreover, central government campaigns for medical

\footnotetext{
${ }^{125}$ For details of a similar entrepreneurial initiative in another provincial city, see June Jones, 'Science, utility and the "second city of the Empire": the sciences and especially the medical sciences at Liverpool University, 1881-1925', Ph.D. thesis, University of Manchester, 1989. For a general discussion of chemical physiology in Britain, see Kohler, op. cit., note 7 above, pp. 40-72.

126 See C. S. Sherrington to J. S. Burdon Sanderson, 17 and 19 February, 8 March 1902, in University College London Library, Burdon Sanderson Papers, MSS Add 179, file 9, ff. 77, 81-6, for a discussion of attempts by anatomists and surgeons at Liverpool to transfer sections of the curriculum from the laboratory sciences to anatomy, apparently in emulation of a similar transfer already made at Birmingham.
} 
reform, including the promotion of medical and especially clinical science, likewise seem to have been dominated by a concern with the education of GPs, the establishment of a hierarchical division of labour, and the creation of a cadre of academic clinician-scientists who would head this new hierarchy. ${ }^{127}$ And if this is the case, it would imply that historians of medical science in other settings would do well to pay more attention, not just to the impact of new medical technologies and the popular prestige that accrued to science, but also to the relationship between the intellectual organization of science and the social organization of medical practice, and especially to the administrative interests that favoured one kind of organization over another.

127 See Steve Sturdy, 'State strategies for health care and the development of clinical science, 1900-1920', paper given to the Wellcome Unit for the History of Medicine, Oxford University, 22 February 1990. 